\title{
1-Kolombiya'da Türkçe öğretimi ve Kolombiyalı öğrencilerin Türkçe öğrenme gereksinimlerinin incelenmesi
}

\section{Memet ABUKAN}

APA: Abukan, M. (2022). Kolombiya'da Türkçe öğretimi ve Kolombiyalı öğrencilerin Türkçe öğrenme gereksinimlerinin incelenmesi. RumeliDE Dil ve Edebiyat Araştırmaları Dergisi, (26), 123. DOI: $10.29000 /$ rumelide.1074500.

$\ddot{\mathbf{O z}}$

Kolombiya ile Türkiye arasında son yıllarda gelişen güçlü ilişkilerin kültür ve eğitim boyutlarına da yansıdığı görülmektedir. TíKA'nın Kolombiya'da kültürel, sosyal, ekonomik alanda yürütmüş olduğu projeler başta olmak üzere ikili ilişkilere dair birçok gelişmenin meyvelerini verdiği söylenebilir. Bu durumu ülkede Türkçe öğrenimine olan talepteki artışla da görebilmek mümkündür. Nitekim yapılan çalışmanın amacı da Kolombiya'da Türkçe öğretiminin genel durumunu değerlendirmek ve ülkede Türkçeyi yabancı dil olarak öğrenen bireylerin hedef dile ilişkin öğrenme gereksinimlerini incelemektir. Bu amaçla alan yazın taranmış fakat ülkede Türkçe öğretimine yönelik faaliyetler yeni olduğu için ilgili konuda pek bir bilgiye ulaşılamamıştır. Bu çerçevede yapılan çalışmada Kolombiya'da Türkçeyi yabancı dil olarak öğrenenler üzerinden hedef dilin gelişimine katkı sunabilecek bulgulara ulaşmak amaçlanmıştır. Bunun için de 2020-2021 eğitim-öğretim yılının bahar ve güz dönemlerinde başkent Bogota'da bulunan Ulusal Üniversitesinde (Universidad Nacional) Türkçeyi seçmeli ders olarak alan öğrencilere Türkçenin Yabancı Dil Olarak Öğretimine Yönelik İhtiyaç Analizi (La análisis sobre la necesita por la enseñanza Turco como idioma extranjero) adlı bir anket uygulanmıştır. Onlardan elde edilen veriler de nicel araştırma yöntemlerinden biri olan tarama modelinin kesitsel tarama türüne göre ele alınıp değerlendirilmiştir. Bunun sonucunda katılımcıların dil gereksinimlerinin Türkiye’yi ve Türkleri kendilerine yakın hissetme durumundan Türkçenin yeni iş imkânları sağlayabilme düşüncesine kadar birçok boyutta incelemesi yapılmış ve bu bulgular alan yazınla desteklenerek yorumlanmıştır. Böylece yapılan çalışmayla özelde Kolombiya'da genelde ise ana dili İspanyolca olan diğer Latin Amerika ülkelerinde Türkçe öğretiminin gelişimi için neler yapılabileceği hususunda çeşitli öneriler geliştirilmiştir.

Anahtar kelimeler: Kolombiya'da Türkçe öğretimi, Güney Amerika'da Türkçe öğretimi, ana dili İspanyolca olanlara Türkçe öğretimi, öğrencilerin Türkçe öğrenme gereksinimleri

\section{Teaching Turkish in Colombia and investigation the Turkish learning requirements of Colombian students}

\begin{abstract}
It is seen that the strong relations that have developed between Colombia and Turkey in recent years are also reflected in the cultural and educational dimensions. It can be said that many developments regarding bilateral relations, especially the projects carried out by TIKA in many cultural, social and economic fields in Colombia, bore fruit. As a matter of fact, it is possible to see this situation with the increase in the demand for Turkish language education in the country. The aim of this study is to reveal the general situation of Turkish teaching in Colombia and to examine the learning needs of the
\end{abstract}

Dr. Öğr. Üyesi, Muş Alparslan Üniversitesi, Sosyal Bilimler Meslek Yüksekokulu, Sivil Havacıllk Kabin Hizmetleri Bölümü (Muş, Türkiye), m.abukan@alparslan.edu.tr, ORCID ID: 000o-0003-3461-0539 [Araştırma makalesi, Makale kayıt tarihi: 09.11.2021-kabul tarihi: 20.02.2022; DOI: 10.29000/rumelide.1074500]

Adres | Address

RumeliDE Dil ve Edebiyat Araştırmalar Dergisi $\quad$ RumeliDE Journal of Language and Literature Studies Osmanağa Mahallesi, Mürver Çiçeği Sokak, No:14/8 $\quad$ Osmanağa Mahallesi, Mürver Çiçeği Sokak, No:14/8

Kadıköy - İSTANBUL / TÜRKIYE 34714 Kadıköy - ISTANBUL / TURKEY 34714 e-posta: editor@rumelide.com e-mail: editor@rumelide.com, tel: +90 505 7958124, +90 2167730616 phone: +90 505 7958124, +90 2167730616 
target language of individuals learning Turkish as a foreign language in the country. For this, the literature was searched, but since the activities for teaching Turkish in the country are new, not much information could be found on this subject. In this context, it is aimed to reach the findings that can contribute to the development of the target language through those who learn Turkish as a foreign language in Colombia. For this purpose, a questionnaire called Needs Analysis for Teaching Turkish as a Foreign Language (La análisis sobre la necesita por la enseñanza Turco como idioma extranjero) was applied to the students who took Turkish as an elective course at National University (Universidad Nacional) in the capital Bogota in the spring and fall semesters of the 2020-2021 academic year. The data obtained from the students were also handled and evaluated according to the cross-sectional survey type of the survey model, which is one of the quantitative research methods. As a result, the language needs of the participants were examined in many dimensions, from the fact that they felt close to Turkey and Turks, to the idea that Turkish could provide new job opportunities, and these findings were interpreted with the support of the literature. Thus, with this study, various suggestions have been developed on what can be done for the development of Turkish teaching in Colombia in particular and in other Latin American countries whose mother tongue is Spanish in general.

Keywords: Teaching Turkish in Colombia, teaching Turkish in South America, teaching Turkish to native Spanish speakers, Turkish learning requirements of students

\section{Giriş}

Güney Amerika kıtasında yer alan ve başkenti Bogota olan Kolombiya Cumhuriyeti 50 milyonun üzerinde nüfusa sahip bir Latin Amerika ülkesidir. Ülkenin resmi dili İspanyolcadır. Bunun nedeni Avrupalıların 1492'de Amerika kıtasını bulmasından sonra İspanyolların bölgede koruyuculuk ve önderliği simgelemek amacıyla "encomienda" adı altında yürüttükleri faaliyetlerle açıklanabilir. Nitekim ülkenin adının da İtalyan kâşif Amerigo Vespucci'nin, İspanyol kâşif Alonso de Ojeda'yla birlikte Kuzey Kolombiya bölgesine ulaştı̆̆ında Kristof Kolomb’un şerefine bölgeye Kolombiya adını verdikleri iddia edilmektedir (Zuluaga González, 2019. 6-7). Kolombiya'nın coğrafi olarak Türkiye’ye uzaklığı bu ülke ya da burada yaşayan halklarla münasebetlerinin de geçmişten bu yana sınırlı olmasına neden olmuştur. Nitekim tarihi kaynaklara bakıldığında Türklerle Kolombiyalılar arasındaki ilişkilere dair çokça bir bilgiye ulaşılamamaktadır. Fakat gerek Afrika'dan buraya gitmek zorunda bırakılmış ya da götürülmüş Müslüman köleler ve gerekse Orta Doğu'dan buraya göç eden çok sayıda Osmanlı tebaasına mensup milletlere yönelik yapılacak araştırmalarla iki ülke arasındaki münasebetlerin tarihi seyrine ışık tutacak pek çok bilgiye ulaşılması mümkündür. Özellikle 19. ve 20. yüzyılın başlarında Suriye, Lübnan, Filistin gibi ülkelerden buraya göç edenlerin Osmanlı pasaportu taşıması onların "Türkler" olarak adlandırılmalarıyla sonuçlanmıştır (Castellanos, 2010; akt. Zuluaga González, 2019). Dolayısıyla Türkiye ve Kolombiya arasındaki ilişkileri doğru okuyabilmek için Osmanlı dönemindeki göç, etnik kimlik vb. birçok hususun araştırılması gerekecek; bunun da iki ülke arasındaki ilişkilerin geliştirilmesine katkısı oldukça fazla olacaktır. Böylelikle bir taraftan dinsel ve kültürel olarak yakın ilişki içerisinde olunan farklı milletlerin, diğer taraftan ise Kolombiyalılarla kurulmuş ilişkilerin ortak paydalar üzerinden ele alınmasına imkân sağlayacak ve bu durum ülkede Türkçe öğretimine yönelik faaliyetlere de yarar sağlayacaktır. Günümüze doğru gelindiğinde ise Türkiye'nin Kolombiya'yla diplomatik ilişkilerinin 1959 yllında başladığı görülmektedir. Fakat bunun ekonomik, ticari, kültürel vb. alanlarda güçlenmesi 2010'dan sonrasına karşılık gelmektedir. Türkiye'nin 2010 yllında Bogota Büyükelçiliği ve Kolombiya'nın da 2011 yllında Ankara Büyükelçiliğini açması ve akabinde iki ülke cumhurbaşkanlarının karşılıklı ziyaretleri ilişkilere güçlü bir ivme kazandırmıştır (Wikipedia, 2021).

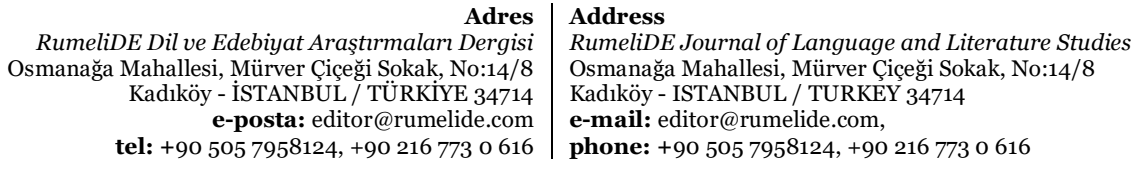


Türk İşbirliği ve Koordinasyon Başkanlığının (TİKA) Kolombiya'da yürütmüş olduğu faaliyetler bunun güçlü bir kanıtı olarak gösterilebilir ve bunun Türkçe eğitimine doğrudan ya da dolaylı desteği ya da etkisi de su götürmez. Nitekim MEB Avrupa Birliği ve Dış İlişkiler Genel Müdürlüğü tarafından Kolombiya'ya okutman gönderilmeyinceye kadar buradaki Türkçe faaliyetlerini TíKA yürütmüştür. Fakat kurumun ülkede dinsel, kültürel, sosyal birçok alanda yürütmüş olduğu faaliyetlerle de dolaylı desteğinden söz etmek mümkündür. Örneğin bu ülkeye göç etmiş olan gerek Orta Doğu gerekse Afrikalı kimi topluluklarla ortak din, kültür vb. nedenlere yönelik yürütülen faaliyetlerin onlarda Türkiye algısını güçlendireceği gibi gelecekte Türkçe öğrenmeye yönelik bir talebi de oluşturacağı düşünülebilir. Yine TíKA'nın Antioquia bölgesinde inşa ettiği Orejon Okulu ve daha başka birçok projeyle de Türkiye'nin tanıtımına da destekleri yadsınamaz. Ayrıca TÍKA'nın ülkede Kolombiya - Bogota Program Koordinasyon Merkezi de bulunmaktadır. Bu merkezin gelecekte faaliyetlerinin daha etkin ve Türkçe öğretimine yönlendirici bir şekilde yürütülmesi ülke adına oldukça faydalı olacaktır (TiKA, 2021). Türkiye ve Kolombiya arasında güçlenen ilişkiler ülkede son yllarda Türkçe öğrenmeye olan talebi artırmıştır. Bunda Navarrete'nin (2020) çalışmasında da vurguladığı üzere birçok Türk dizisinin ülkede en çok izlenen yayınlar arasında olması gösterilebilir (s. 52-54). Nitekim başkent Bogota'da bulunan Ulusal Üniversite (Universidad Nacional) ile Kolombiya Gündüz Okulu Üniversitesinde (Universidad Externado de Colombia) Türkçe ve Türk kültürü dersleri verilmeye başlanmış ve her yll bu derslere olan talebin arttığı görülmektedir. 2021 yll itibariyle Ulusal Üniversitesinde Türkçe 1, Türkçe 2 ve Türk Kültürü dersleri seçmeli olarak okutulmaktadır. Sınırlı sayıda kontenjan ayrılan bu derslere yoğun bir talep olduğu tespit edilmiştir. Nitekim 2021 yllında 5o'den fazla öğrenci burada Türkçe öğrenmekte ve Türkiye'den görevli bir okutman aracılığıyla bu dersler yürütülmektedir. Ayrıca farklı üniversitelerde de Türkçeye olan taleple karşılaşıldığı bilinmektedir. Burada da Türkçe öğretimi üzerine çalışmaların yapılması gerek ülke tanıtımı gerekse ikili ilişkilerin geleceğine yönelik katkısı açısından önemli görülmelidir.

\subsection{Araştırmanın amacı ve önemi}

Bu araştırma, Güney Amerika ülkelerinden biri olan Kolombiya'da Türkçe öğretiminin durumunu ve yabancı dil olarak Türkçe öğrenen bireylerin dil gereksinimlerini tespit etmek amacıyla yapılmıştır. Çalışmayla Kolombiya'da Türkçe öğretimine yönelik neler yapılması gerektiğine açıklık kazandırılacağı gibi İspanyolca konuşan diğer Güney Amerika ülkelerinde de Türkçe öğrenenlerin dil gereksinimlerine etki eden faktörler için de bir öngörü oluşturacağı düşünülmektedir.

\subsection{Araştırmanın problem cümlesi}

Çalışma, "Kolombiya'da yabancı dil olarak Türkçe öğrenen bireylerin dil gereksinimleri nelerdir?" problemine yönelik oluşturulmuştur. Fakat bu soru kapsamında konunun bütünlüğü ve anlaşlabilmesi adına bireylerin Türkçe öğrenme gereksinimleri yaşı, öğrenim durumu, cinsiyeti, ana dili vb. birçok husus da alt problemler olarak değerlendirilmiştir.

\section{Yöntem}

\subsection{Araştırmanın modeli}

Çalışmada nicel araştırma yönteminin tarama modelinden yararlanılmıştır. Var olan bir durumu olduğu gibi incelemeyi amaçlayan araştırmalardan yararlanılan bu modelin üç farklı türü vardır. Bunlar boylamsal, geçmişe dönük ve kesitseldir. Nitekim hazırlanan çalışmada da modelin kesitsel türünden

\footnotetext{
\begin{tabular}{r|l} 
Adres & Address \\
RumeliDE Dil ve Edebiyat Araştırmaları Dergisi & RumeliDE Journal of Language and Literature Studies
\end{tabular} Osmanağa Mahallesi, Mürver Çiçeği Sokak, No:14/8 $\quad$ Osmanağa Mahallesi, Mürver Çiçeği Sokak, No:14/8 Kadıköy - ISTANBUL / TURKIYE 34714 Kadıköy - ISTANBUL / TURKEY 34714 e-posta: editor@rumelide.com e-mail: editor@rumelide.com, tel: +90 505 7958124, +90 2167730616 phone: +90 505 7958124, +90 2167730616
} 
yararlanarak araştırılacak durum ya da tasvir edilecek değişkenin ölçümünü yapabilmek adına evrenin bir bölümü üzerinden verilerin elde edilip ölçülmesi amaçlanmıştır. (Aypay vd., 2009; Büyüköztürk, vd., 2014; Karasar, 1999).

\subsection{Verilerin toplanması ve analizi}

Araştırmada verilerin toplanmasında ilkin Kolombiya'da Türkçe öğretiminin nerelerde gerçekleştiğinin belirlenmesine çalışılmıştır. Daha sonra ise ilgili ülkede Türkçe öğrenen bireylerin hedef dile ilişkin gereksinimlerinin ne olduğunu belirlemek ve verileri elde etmek amaciyla alan yazın taraması yapılmıştır. Bunun sonucunda çalışmada Nihal Çalışkan ve Önder Çangal tarafından geliştirilen bir anketten yararlanılmıştır (Çangal, 2013). Gerek anketin kullanılması gerekse anket üzerinde ülkeye yönelik bazı ufak değişiklikler yapma adına kendilerine ulaşılmış ve gerekli izinler alındıktan sonra dil ihtiyaç anketine son şekli verilmiştir. Toplam 33 soru olarak düzenlenen anket formunun ilgili ülkede uygulanabilmesi adına T.C. Bogota Büyükelçiliğinden gerekli izinler alındıktan sonra çalışmanın uygulanmasına geçilmiştir. İlgili anket, 2021 eğitim-öğretim yılının bahar döneminde başkent Bogota'da bulunan Ulusal Üniversitesinde Türkçeyi yabancı dil olarak öğrenen öğrencilere uygulanmış ve böylece verilerin elde edilmesi tamamlanmıştır. Tam olarak 32 öğrenciden elde edilen verilerin analizi ise alan yazın dikkate alınarak şekillerle gösterilip yorumlanmıştır.

\section{Bulgular}

Kolombiya'da Türkçeyi yabancı dil olarak öğrenenlerin hedef dile ilişkin dil gereksinimlerini tespit etmek amacıyla Türkçenin Yabancı Dil Olarak Öğretimine Yönelik İhtiyaç Analizi (La análisis sobre la necesita por la enseñanza Turco como idioma extranjero) adlı anket çalışmasından yararlanılmıştır. Ulusal Üniversitesinde Türkçeyi seçmeli ders olarak alan öğrencilere uygulanan çalışmanın sonucunda elde edilen bulguların konuya göre dağılımı şekiller halinde aşağıda gösterilmiştir:

\subsection{Kolombiya'da Türkçe öğrenen katılımcıların dil gereksinimlerinin cinsiyete göre dağılımı:}
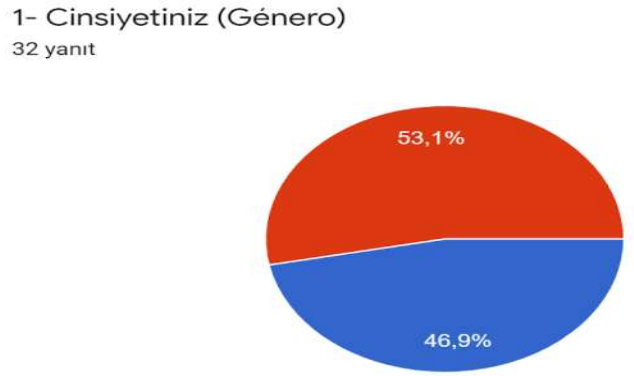

Kadın ( mujer)

Erkek (hombre)

Şekil 1. Türkçe öğrenme gereksinimlerinin cinsiyete göre dağılımı

Şekil 1'de katılımcıların cinsiyete göre dağılımına bakıldı̆̆ında \%53,1’inin erkek, \%46,9'unun ise kadın olduğu görülmektedir. Dolayısıyla elde edilen bulgulardan cinsiyet faktörü üzerinden ciddi bir farklılı̆̆ın olmadığı tespit edilmiştir.

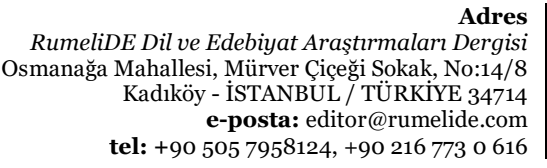

dres

8

Address

RumeliDE Journal of Language and Literature Studies

Osmanağa Mahallesi, Mürver Çiçeği Sokak, No:14/8

Kadıköy - ISTANBUL / TURKEY 34714

e-mail: editor@rumelide.com,

phone: +90 5057958124, +90 2167730616 


\subsection{Kolombiya'da Türkçe öğrenen katılımcıların dil gereksinimlerinin mesleğe göre dağılımı:}
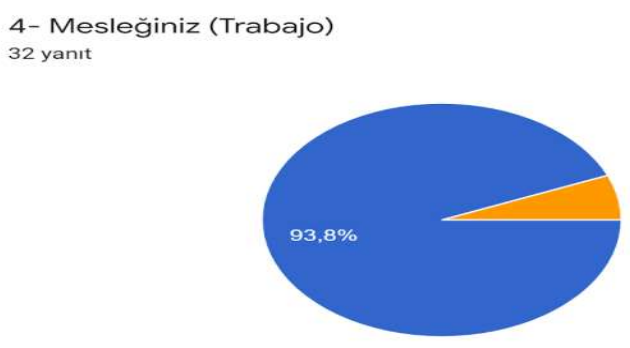

Şekil 4. Türkçe öğrenme ihtiyacının mesleğe göre dağılımı

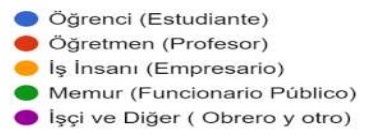

Issçi ve Diğer (Obrero y otro)

Şekil 4'te Türkçe öğrenenlerin mesleki dă̆ılımı gösterilmiştir. Bu dağılıma göre katılımcıların yüzde 93,8’inin öğrenci oldukları saptanmıştır. Geriye kalan katılımcıların da iş insanı oldukları belirlenmiştir. Bu dağılımlar Kolombiya'da Türkçe öğrenenlerin mesleklerinin çeşitlilik göstermediğinin kanıtıdır. Gelecekte ülkede kurs merkezlerini açılması ve böylelikle öğrenci sayısının artmasının bu çeşitliliği etkileyeceği düşünülmektedir.

\subsection{Kolombiya'da Türkçe öğrenen katılımcıların dil gereksinimlerinin uyruğa göre dağılımı:}
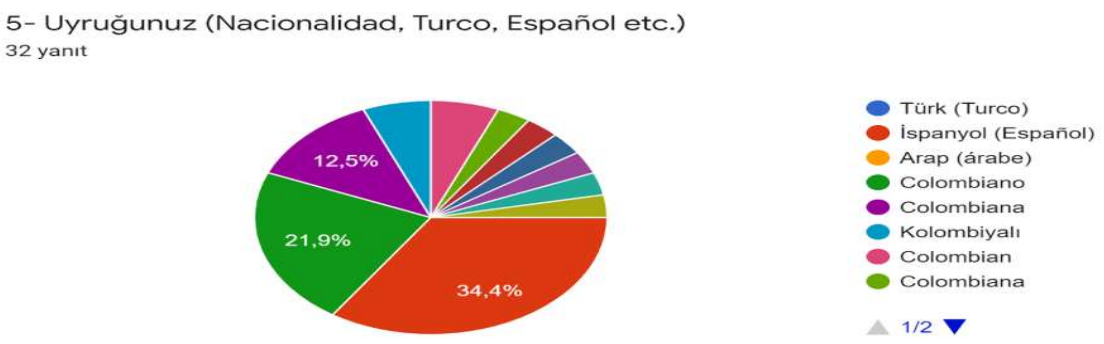

Şekil 5. Türkçe öğrenme gereksiniminin uyruğa göre dă̆̆lımı

Şekil 5’te Kolombiya'da Türkçe öğrenen katılımcıların uyruğa göre dağllımı gösterilmiştir. Kolombiya, Mestizolar gibi gruplar başta olmak üzere etnik çeşitliliği oldukça yüksek bir ülke. Bu nedenle belirtilen soru kapsamında bu hususa dikkat edilse de bir hata yapıldığı söylenebilir. Çünkü sorunun seçenekleri Türk, Arap, İspanyol ve Diğer şeklindeydi. Ve Diğer başlığı altında da katılımcılardan mensup oldukları etnik yapı ya da millete ait olduklarının yazılması istenmişti. Fakat katılımcıların çoğunluğunun Diğer şıkkına Kolombiyalı/Colombian vs. yazdıkları tespit edilmiştir. Dolayısıyla katılımcıların çoğunun Kolombiyalı üst kimliğiyle uyruklarını belirttikleri anlaşılmıştır. Hatta İspanyol seçeneğini belirten katılımcıların çoğunun ya da tamamının da Kolombiyalı oldukları öngörülebilir. Dolayısıyla uyruğa yönelik yapılan bir çalışmada Kolombiyalı seçeneğinin olmaması büyük bir hata olmuştur. Böyle bir hatanın yapılmaması için araştırmacıların dikkat etmesi gerektiği söylenebilir. Fakat elde edilen dağılımdan katılımcıların büyük bir çoğunluğunun (belki tamamının!) Kolombiyalı olduğu tespit edilmiştir.

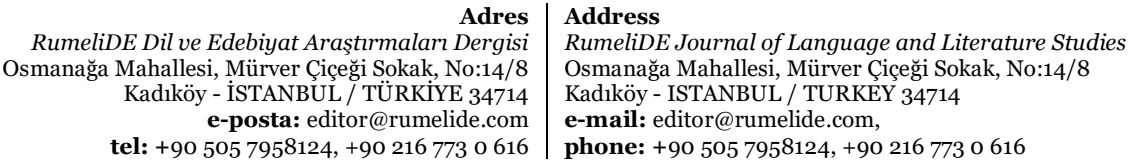


3.6. Kolombiya'da Türkçe öğrenen katılımcıların dil gereksinimlerinin ana dile göre dağılımı:
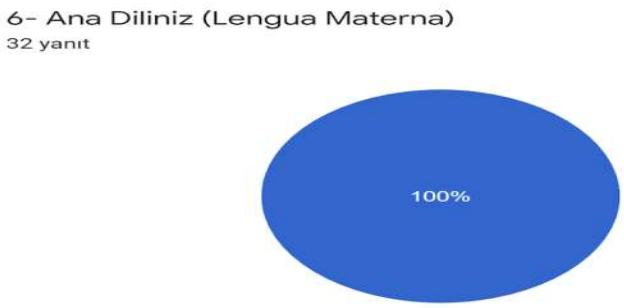

Şekil 6. Türkçe öğrenme gereksiniminin ana dile göre dağılımı

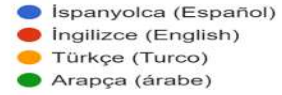

Arapça (árabe)

Şekil 6'da Kolombiya'da Türkçe öğrenen katılımcıların tamamının ana dilinin İspanyolca olduğu saptanmıştır. Nitekim ülkenin resmi dilinin de İspanyolca oluşuyla bu oran gayet olağandır.

\subsection{Kolombiya'da Türkçe öğrenen katılımcıların dil gereksinimlerinin ikinci dile göre dağılımı:}

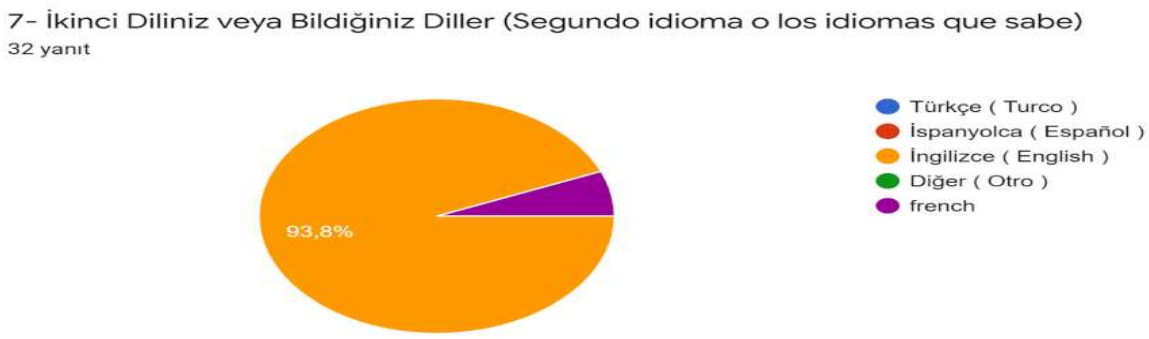

Şekil 7. Türkçe öğrenme gereksiniminin ikinci dile göre dağılımı

Şekil 7'de Kolombiya'da Türkçe öğrenen katılımcıların ikinci dile göre dağılımına bakıldığında \%93,8 oranında İngilizce olduğu saptanmıştır. Geriye kalan \%6,2'sinin de Fransızcayı bildikleri tespit edilmiştir. Dolayısıyla İngilizce ve Fransızcanın Kolombiyalı öğrenciler arasında bilinen diller olduğu söylenebilir.

\subsection{Kolombiya'da Türkçeyi yabancı dil olarak öğrenmeye devam eden bireylerin dil gereksinimlerinin Türkçe öğrenme süresine göre dağılımı:}

8. Ne kadar zamandır Türkçe öğreniyorsunuz? (Türkçe öğrenmeye devam edenler cevaplayacak) (¿Cuánto tiempo lleva aprendiendo Turco? (Los que siguen aprendiendo Turco deben contestar) 32 yanit
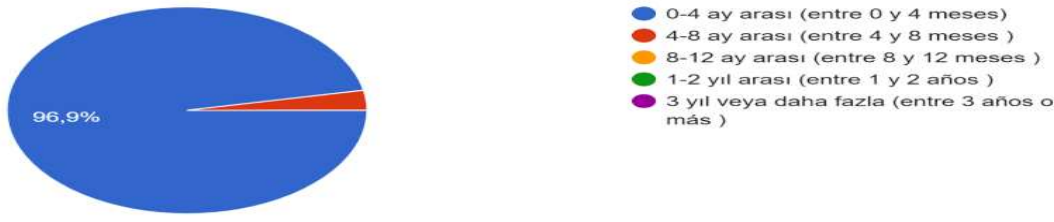

Şekil 8. Bireylerin Türkçe öğrenme süresine göre dağılımı

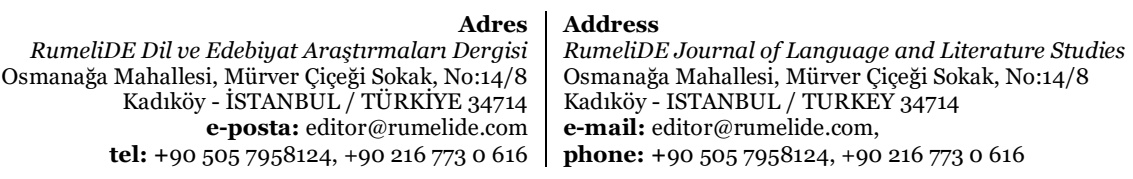


Şekil 8'de Kolombiya'da Türkçe öğrenen katılımcıların Türkçe öğrenme süreleri gösterilmiştir. Buna göre katılımcıların tamamına yakınının "o-4 ay arası” seçeneğini işaretledikleri görülmüştür. Yüzde 5’e yakın bir oranın da 4-8 ay arası bir sürede Türkçe öğrendikleri saptanmıştır. Bu öğrencilerin de A2 düzey öğrenciler olduğu söylenebilir.

\subsection{Kolombiya'da Türkçeyi yabancı dil olarak öğrenen B2 ve C1 düzeyde bireylerin dil gereksinimlerinin Türkçe öğrenme süresine göre dağılımı:}

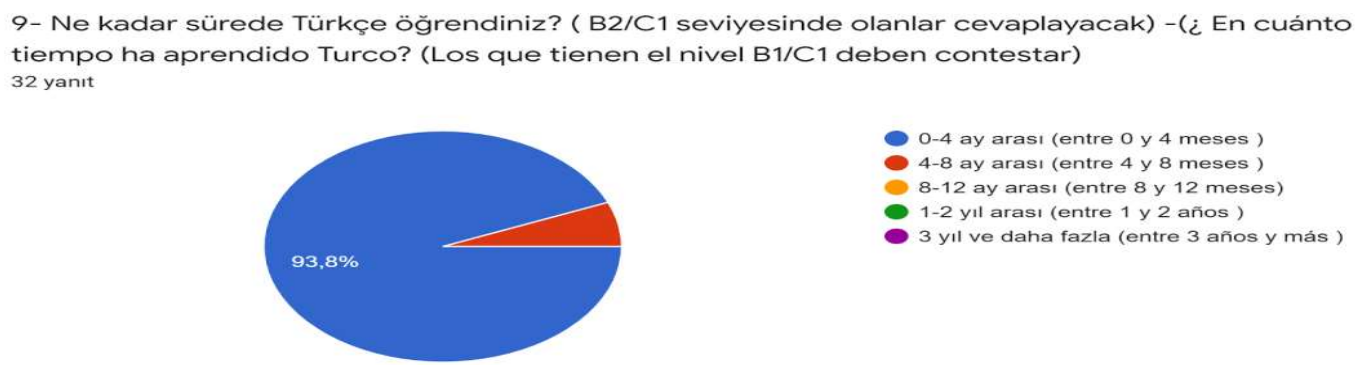

Şekil 9. B2 ve C1 düzey bireylerin Türkçe öğrenme süresine göre dă̆llımı

Çalışmada B2 ve C1 düzey öğrenciler varsa bunların ne kadar sürede belirlenen düzeye geldiklerinin saptanmasıyla ana dili İspanyolca olan öğrencilerin gelişim düzeyiyle ilgili bir öngörüye ulaşmak amaçlanmıştır. Bu çerçevede $\mathrm{B} 2$ ve $\mathrm{C} 1$ düzey olan öğrencilerin cevaplanması kaydıyla onlara ne kadar sürede Türkçe öğrendikleri sorulmuştur. Fakat Şekil 9'da görüldüğü üzere öğrencilerin \%93,8'i (3o kişi) o-4 ay arasında \%6,2'si (2 kişi) ise 4-8 ay arasında Türkçe öğrendiklerini belirtmişlerdir. Elde edilen bu sonuçlardan katılımcıların soruda geçen “...B2 ve $\mathrm{C} 1$ sevide olanla cevaplayacak” ibaresini gözden kaçırdıkları anlaşılmaktadır. Bu çerçevede bu soru kapsamında tespit edilen değerlerin bir doğruluk taşımadığı söylenebilir. Sadece iki öğrencinin 4 ve 8 ay arasında Türkçe öğrendiklerinin tespit edilmesiyle onların düzeylerinin temel seviye olmadığı öngörülebilir. Bununda B1 ve sonrası bir düzeye karşılık geldiği şeklinde bir çıkarımda bulunmak mümkündür.

\subsection{Kolombiya'da Türkçe öğrenen bireylerin dil gereksinimlerinin Türkçe öğrenme yerlerine göre dağılımı:}

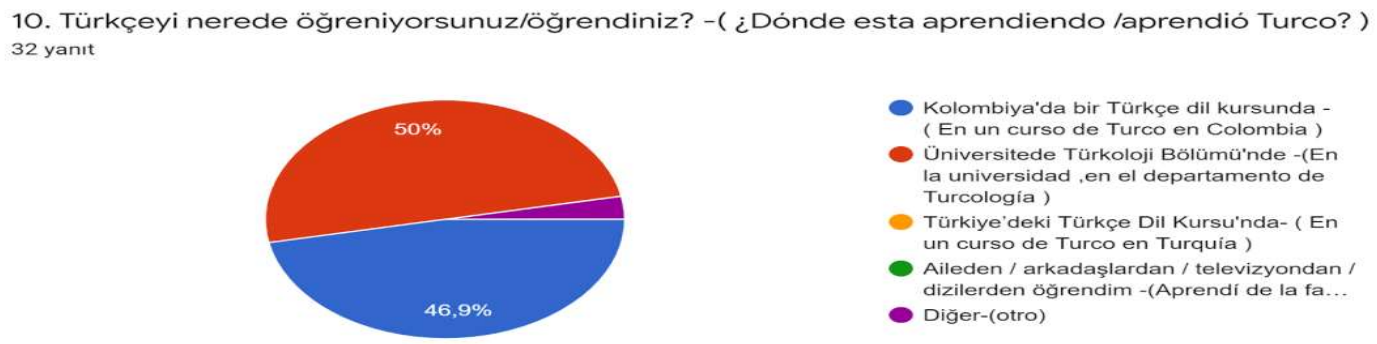

Şekil 10. Bireylerin Türkçe öğrenme yerlerine göre dağılımı

Şekil 10'da Kolombiya'da Türkçe öğrenen katılımcıların Türkçe öğrenme yerlerine ilişkin dağılımı gösterilmiştir. Buna göre katılımclların neredeyse tamamının üniversitede ve bir dil kursunda öğrendikleri tespit edilmiştir. Geriye kalan \%3,1'inin de "diğer" şıkkını işaretledikleri anlaşılmaktadır.

\begin{tabular}{|c|c|}
\hline Adres & Address \\
\hline RumeliDE Dil ve Edebiyat Araştırmaları Dergisi & RumeliDE Journal of Language and Literature Studies \\
\hline smanağa Ma & ağa Mahallesi, Mürver Çiçeği Sokak, No:14/8 \\
\hline $\begin{array}{r}\text { Kadıköy - İSTANBUL / TÜRKIYY } 34714 \\
\text { e-posta: editor@rumelide.com } \\
\text { tel: +90 505 7958124, +90 } 2167730616\end{array}$ & $\begin{array}{l}\text { Kadıköy - ISTANBUL / TURKEY } 34714 \\
\text { e-mail: editor@rumelide.com, } \\
\text { phone: +90 505 7958124, +90 } 2167730616\end{array}$ \\
\hline
\end{tabular}




\subsection{Kolombiya'da Türkçe öğrenen bireylerin dil gereksinimlerinin Türkiye'de bulunma durumuna göre dağılımı:}

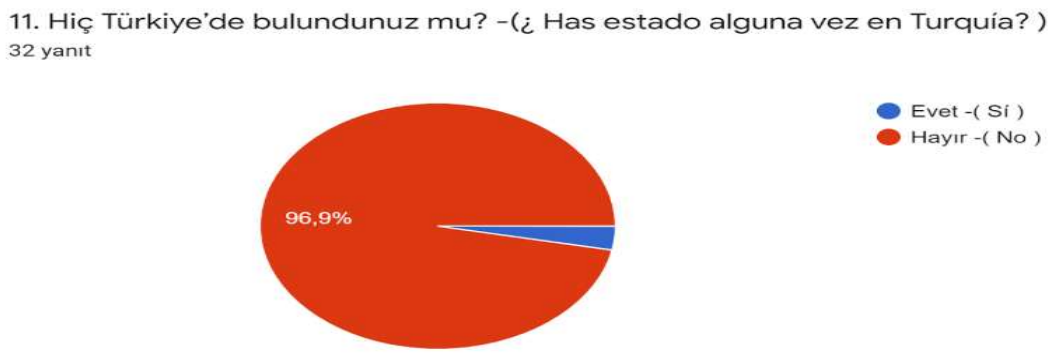

Şekil 11. Katılımcıların Türkiye'de bulunma durumlarına göre dağılımı

Şekil 11'de de görüleceği üzere Kolombiya'da Türkçe öğrenen katılımcıların \%96,9'unun Türkiye’ye gelmedikleri belirlenmiştir. Bir Güney Amerika ülkesi olan Kolombiya’nın Türkiye’ye uzaklığı doğal olarak katılımcıların Türkiye'ye gelmediklerini göstermektedir. Fakat buna rağmen \%3,1’inin Türkiye’de bulunmuş olması önemli bir veridir.

\subsection{Kolombiya'da Türkçe öğrenen bireylerin dil gereksinimlerinin Türkiye'de bulunma süresine göre dağılımı:}

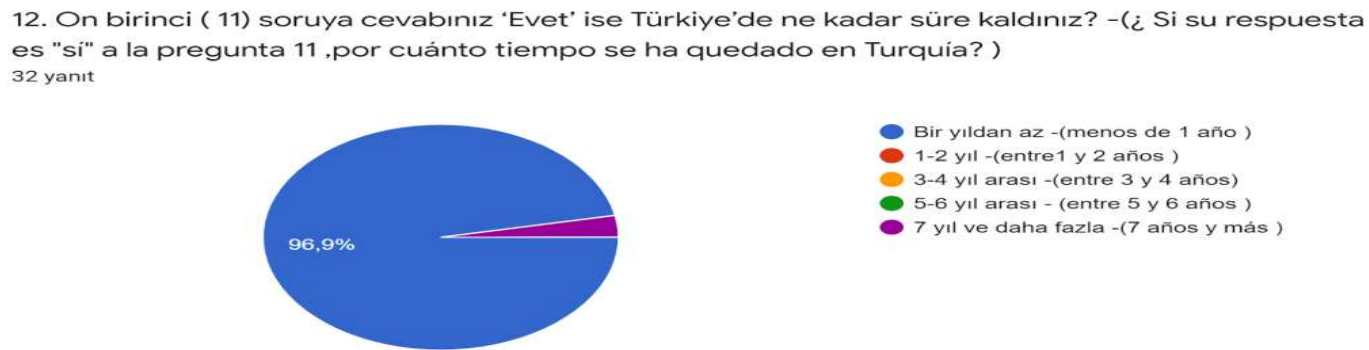

Şekil 12. Bireylerin Türkiye'de bulunma süresine göre dağılımı

Şekil 12'de katılımcıların Türkiye'de kalma sürelerine ilişkin dağılımı gösterilmiştir. Buna göre \%96,9'unun bir yıldan az bir sürede Türkiye'de bulundukları saptanmıştır. Fakat bazı katılımcıların da 7 yıl veya daha fazla Türkiye'de bulundukları belirlenmiştir.

RumeliDE Dil ve Edebiyat Arasturmaluri Adres Osmanağa Mahallesi, Mürver Ciçeği Sokak, No:14/8 Kadıköy - ÍSTANBUL / TÜRKIYE 34714 e-posta: editor@rumelide.com tel: +90 $5057958124,+902167730616$
Address

RumeliDE Journal of Language and Literature Studies

Osmanağa Mahallesi, Mürver Çiçeği Sokak, No:14/8

Kadıköy - ISTANBUL / TURKEY 34714

e-mail: editor@rumelide.com

phone: +90 $5057958124,+902167730616$ 


\subsection{Kolombiya'da Türkçe öğrenen bireylerin dil gereksinimlerinin Türkiye'de bulunma nedenine göre dağılımı:}

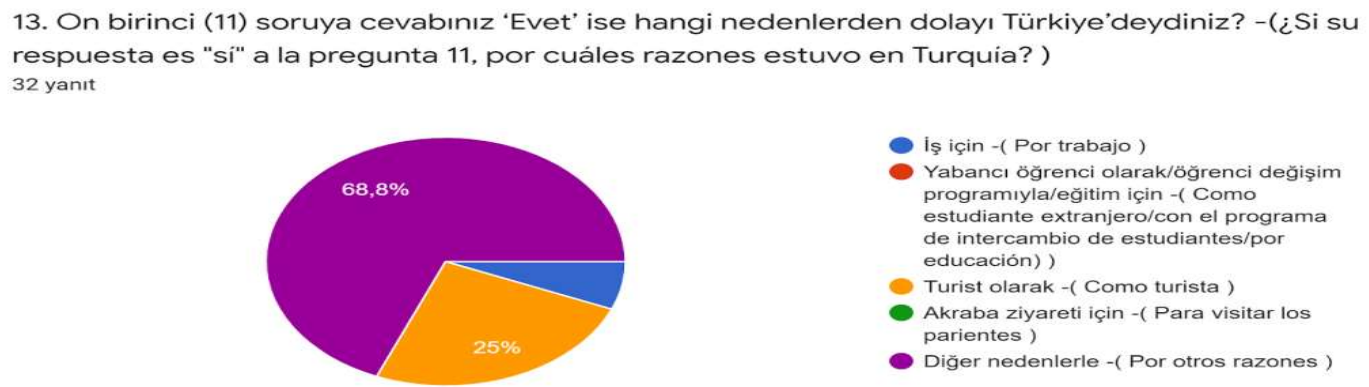

Şekil 13. Bireylerin Türkiye'de bulunma nedenlerine göre dağılımı

Şekil 13’te Kolombiya'da Türkçe öğrenenlerin Türkiye'de bulunma gerekçelerine ilişkin dağılımları gösterilmiştir. Katılımcıların \%68,8’i “diğer nedenlerle” seçeneğini işaretledikleri saptanmıştır. Turist olarak bulunanların oranı ise \%25'tir. Geriye kalanların ise iş amacıyla Türkiye'de bulundukları belirlenmiştir.

\subsection{Kolombiya'da Türkçe öğrenen bireylerin dil gereksinimlerinin sınıf dışında Türkçeyi kullanma durumuna göre dağılımı:}

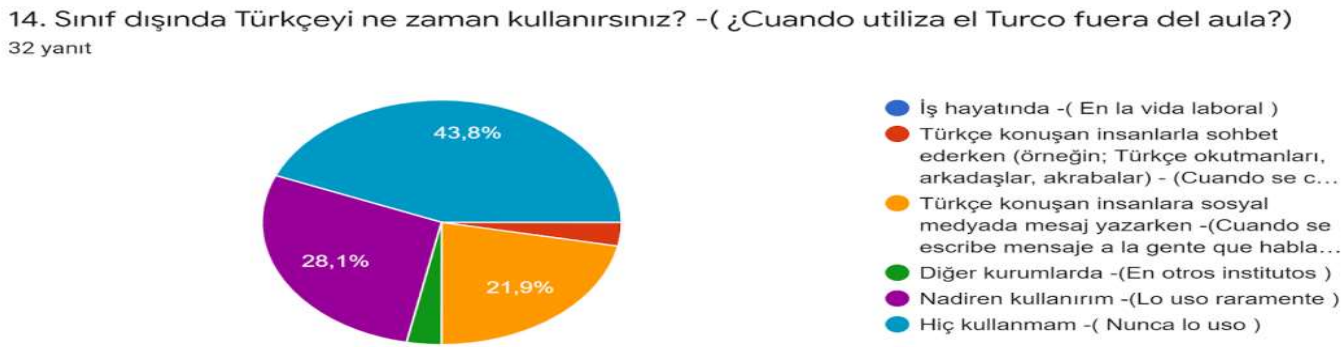

Şekil 14. Bireylerin sınıf dışında Türkçeyi kullanma durumuna göre dağılımı

Şekil 14'te Kolombiya'da Türkçe öğrenen bireylerin sınıf dışında hedef dili nerede kullandıklarına ilişkin dağılımı gösterilmiştir. Buna göre katılımcıların \%44'e yakını Türkçeyi sınıf dışında hiç kullanmadıklarını, \%28,1’i ise nadiren kullandıklarını belirtmiştir. Diğer katılımcıların büyük bir çoğunluğu ise sosyal medyada Türkçe bilenlerle mesajlaşırken Türkçeyi kullandıklarını belirtmişlerdir. Dolayısıyla ilgili ülkede Türkçe konuşanların sınırlı oluşu katılımcılar için dili kullanma noktasında bir sınırlılık oluşturmaktadır.

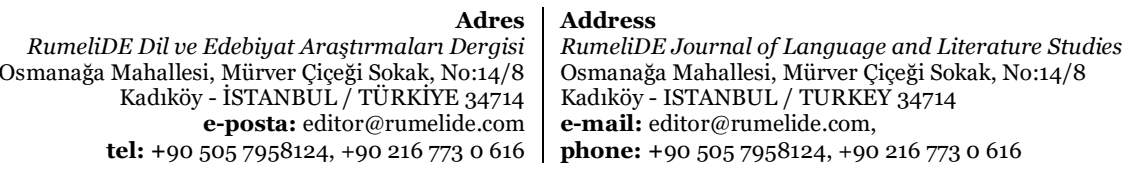


3.15. Kolombiya'da Türkçe öğrenen bireylerin dil gereksinimlerinin Türkiye'yi ziyaret etme nedenine göre dağılımı:

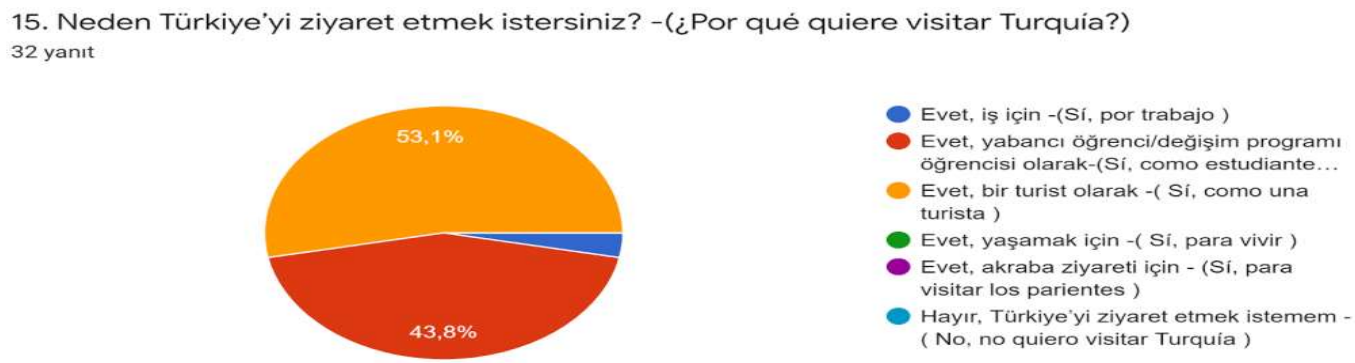

Şekil 15. Bireylerin Türkiye’yi ziyaret etme nedenlerine göre dağılımı

Şekil 15'te Kolombiya'da Türkçe öğrenen katılımclların Türkiye'yi ziyaret etme nedenlerine ilişkin dağılımı gösterilmiştir. Öğrencilerin yarısından fazlası, \%53,1'i, turist olarak; \%43,8’i ise öğrenci değişim programı için Türkiye’ye gelmek istediklerini belirtmişlerdir. Bunun dışında \%5’e yakın bir oranda da iş amaciyla gelmek isteyenlerin de olduğu görülmektedir.

\subsection{Kolombiya'da Türkçe öğrenen bireylerin dil gereksinimlerinin Türkiye'deki yükseköğretim kurumlarında eğitim alma isteğine göre dağılımı:}

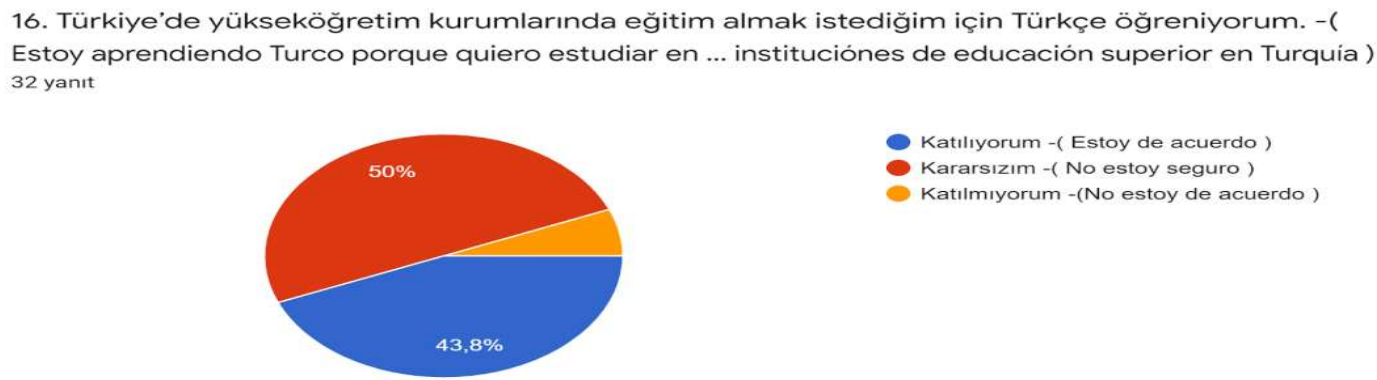

Şekil 16. Bireylerin Türkiye’yi ziyaret etme nedenlerine göre dağılımı

Şekil 16'da Katılımcıların Türkiye'de bulunan bir yükseköğretim kurumunda eğitim alma isteğine yönelik oranlar gösterilmiştir. Katılımcıların \%43’ü Türkiye'de eğitim almak istediğini belirtmiştir. Kararsızların oranı ise oldukça yüksektir. Buna göre Türkçe öğrenenlerin yarısının bu konuda bir belirsizlik içerisinde oldukları saptanmıştır. "Katılmıyorum" diyenler ise \%7'ye yakın bir oranla sınırlıdır. Bu oranlara göre denilebilir ki ülkede Türkiye'nin tanıtımına yönelik faaliyetlerin artırılması gelecekte daha fazla talebin oluşmasına imkân sağlayabilir.

RumeliDE Dil ve Edebiyat Arasturmalar Adres Osmanağa Mahallesi, Mürver Ciçeği Sokak, No:14/8 Kadıköy - İSTANBUL / TÜRKIYE 34714 e-posta: editor@rumelide.com tel: +90 $5057958124,+902167730616$
Address

RumeliDE Journal of Language and Literature Studies

Osmanağa Mahallesi, Mürver Çiçeği Sokak, No:14/8

Kadıköy - ISTANBUL / TURKEY 34714

e-mail: editor@rumelide.com,

phone: +90 $5057958124,+902167730616$ 


\subsection{Kolombiya'da Türkçe öğrenen bireylerin dil gereksinimlerinin uzmanlık alanlarıyla ilgili olarak Türkçeyi öğrenebilme amaçlarına göre dağılımı:}

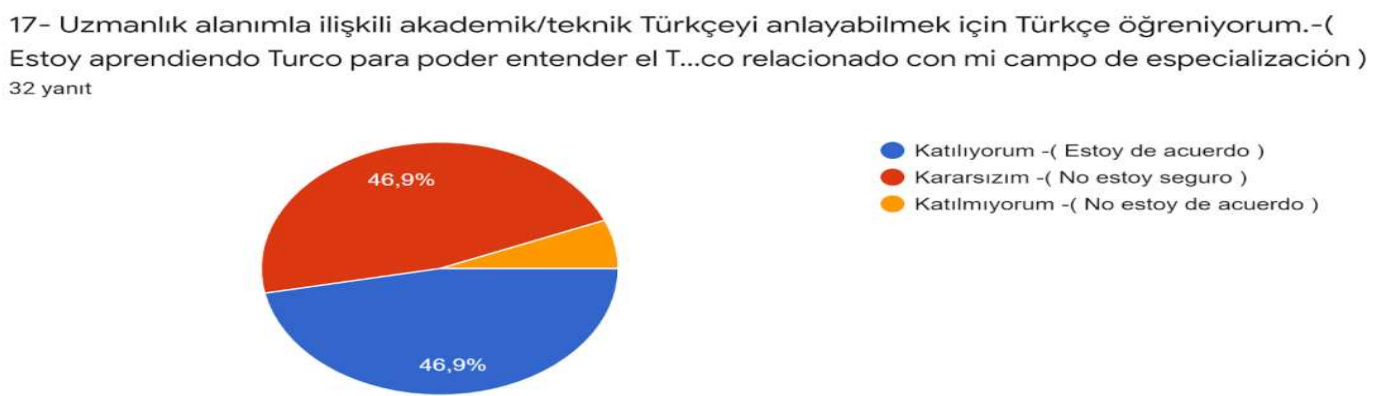

Şekil 17. Bireylerin uzmanlık alanına ilişkin Türkçe öğrenme amaçlarına göre dağılımı

Şekil 17’de Katılımcıların Türkçe öğrenme gereksinimlerinin uzmanlık alanlarılı ilişkili dağılımına bakıldığında \%46,9 oranında öğrencilerin bu düşünceye katıldıkları görülmektedir. Aynı oranda kararsızların da olduğu saptanmıştır. Buna rağmen "katılmıyorum" diye görüş bildirenlerin oranı ise hayli düşüktür. Dolayısıyla kararsızlarla birlikte ülkede Türkçe öğrenenlerin, hedef dil konusunda daha da yetkin olma isteği taşıdıkları söylenebilir.

\subsection{Kolombiya'da Türkçe öğrenen bireylerin dil gereksinimlerinin resmi görüşmelere katılabilme (burs/iş vb. ) isteğine göre dağılımı:}

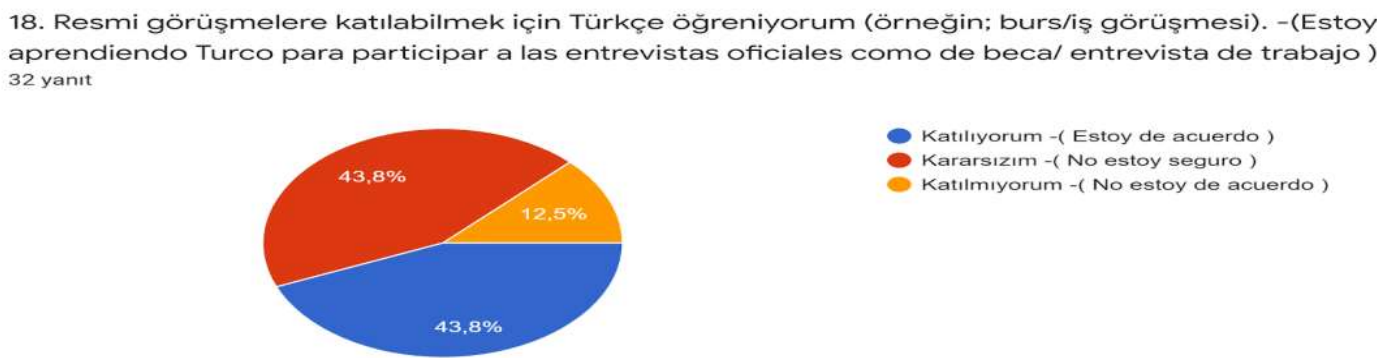

Şekil 18. Bireylerin dil gereksinimlerinin resmi görüşmelere katılabilme amacına göre dağılımı

Şekil 18'de görüldüğüü üzere Kolombiya'da Türkçe öğrenen katılımclların \%43,8’i burs, iş vb. resmi işlere katılabilmek amacıyla Türkçe öğrenmek istediklerini belirtmişlerdir. Fakat "katılıyorum", diyenlerin oranı ise \%12,5'le sınırlı kalmıştır. Kararsızlarla birlikte katılımcıların \%9o'a yakınının konuya yaklaşımının bu ülkede Türkçe öğrenme faaliyetlerinin amacını ortaya koyması bakımından önemli görülebilir.

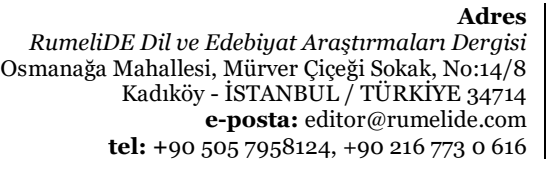

dres

isi

RumeliDE Journal of Language and Literature Studies

Osmanağa Mahallesi, Mürver Çiçeği Sokak, No:14/8

Kadıköy - ISTANBUL / TURKEY 34714

e-mail: editor@rumelide.com,

phone: +90 505 7958124, +90 2167730616 


\subsection{Kolombiya'da Türkçe öğrenen bireylerin dil gereksinimlerinin Türkiye’ye tatile gitme isteğine göre dağılımı:}

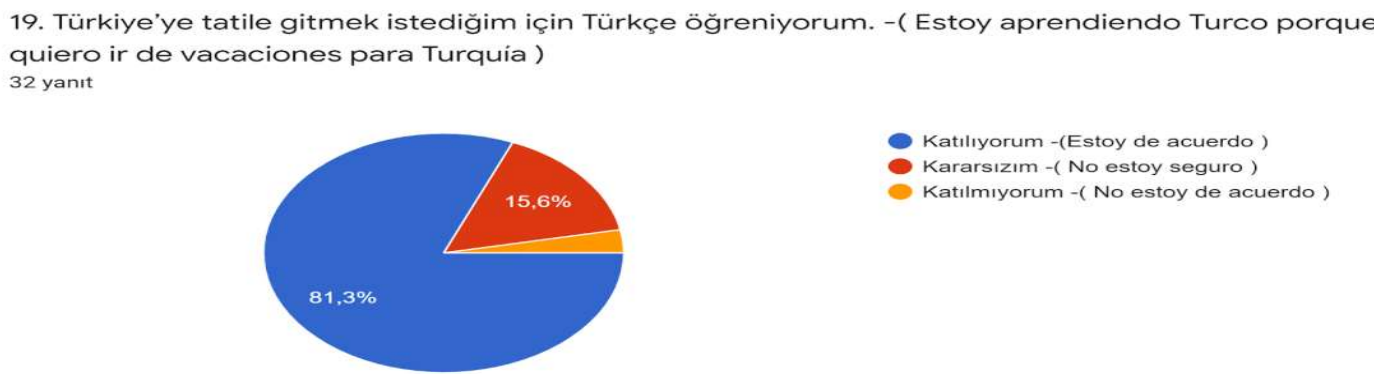

Şekil 19. Bireylerin dil gereksinimlerinin Türkiye’ye tatile gitme amacına göre dağılımı

Şekil 19'da Kolombiya'da Türkçe öğrenen katılımcıların, kararsızlarla birlikte, \%95’ten fazlasının Türkiye’ye tatile gitme amacı taşıdıkları tespit edilmiştir. Bu çerçevede Türkiye’nin turizm alanında ülke tanıtımına yönelik çalışmalar yürütmesi faydalı olacaktır.

\subsection{Kolombiya'da Türkçe öğrenen bireylerin dil gereksinimlerinin Türkiye'de yaşama isteğine göre dağılımı:}

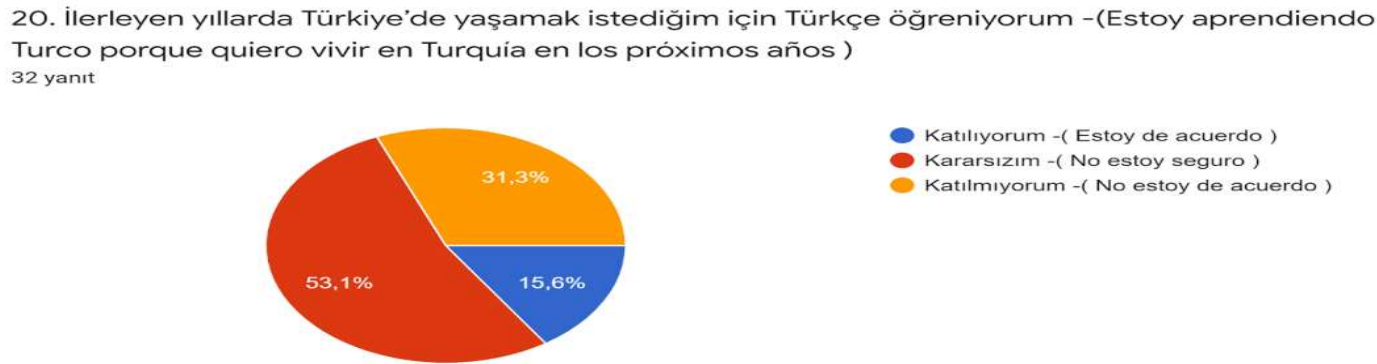

Şekil 20. Bireylerin dil gereksinimlerinin Türkiye'de yaşama isteğine göre dağılımı

Şekil 20'de Kolombiya'da Türkçe öğrenen katılımcıların hedef dil gereksinimlerinin Türkiye'de yaşama isteğine yönelik dağılımına bakıldığında katılımcıların \%31,3 üü buna katılmadıklarını belirtmişlerdir. Fakat \%15,6'sı "katılıyorum", \%53,1'i ise "kararsızım" cevabını vermiştir. Dolayısıyla \%70'e yakın bir oranda katılımcıların Türkiye'de yaşamak amacıyla Türkçe öğrenmek istediklerine ilişkin bir düşünce taşıdı̆̆ı anlaşılabilir. Bu oran ülkede Türkçe öğrenenlerin Türkiye’ye yönelik algılarını yansıtması bakımından önemli görülmelidir.

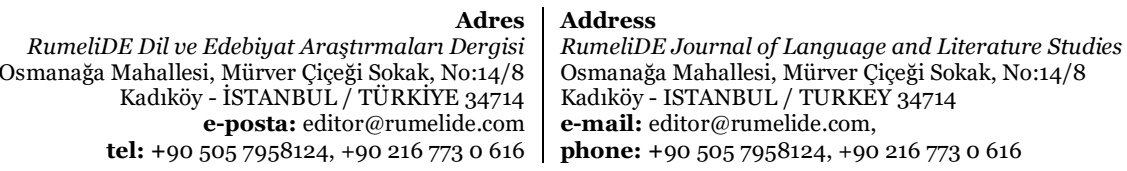




\subsection{Kolombiya'da Türkçe öğrenen bireylerin dil gereksinimlerinin yeni iş imkânları sağlayabilme düşüncesine göre dağılımı:}

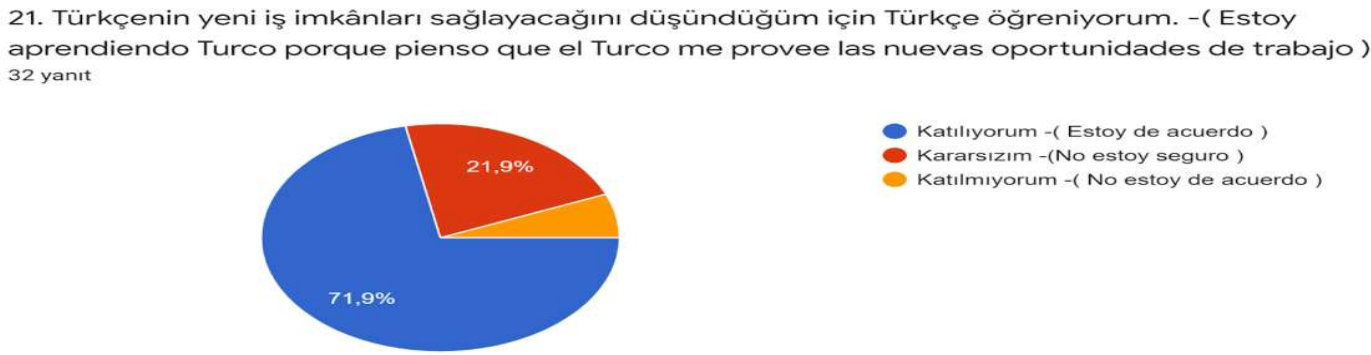

Şekil 21. Bireylerin dil gereksinimlerinin yeni iş imkânları sağlayabilme amacına göre dağıllımı

Şekil 21'de Kolombiya'da Türkçe öğrenen katılımcıların \%71,9'unun Türkçe öğrenmenin onlara yeni iş imkânları oluşturacağı düşüncesini taşıdıkları anlaşılmaktadır. Kararsızlarla birlikte bu oran \%9o'dan fazla bir orana yükselmektedir. Dolayısıyla Türkçe öğrenme noktasında öğrencilerin yeni imkânlara kavuşabilme ümidine yönelik bir düşünce taşımaları burada Türkçe faaliyetlerinin geliştirilmesi başta olmak üzere iki ülke arasındaki ilişkilerin daha da ileriye taşınması noktasında da bir fikir verdiği söylenebilir.

\subsection{Kolombiya'da Türkçe öğrenen bireylerin dil gereksinimlerinin Türkiye'de alanla ilgili bir meslekte çalışabilme isteğine göre dağılımı:}

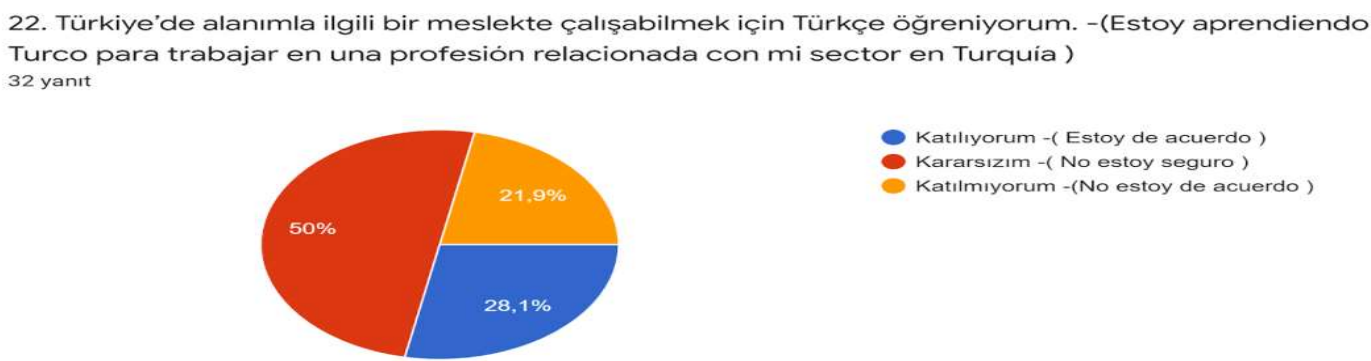

Şekil 22. Bireylerin dil gereksinimlerinin Türkiye'de meslekte çalışabilme amacına göre dağılımı

Şekil 22'de katılımcıların Türkiye'de bir meslek alanında çalışabilme amacıyla Türkçe öğrenme gereksinimlerine bakıldığında öğrencilerin \%28'inin bu hususa "katılıyorum" cevabı verdikleri görülmektedir. Buna rağmen "katılmıyorum" diyenlerin oranı ise \%21 ile sınırlı kalmıştır. Katılımcıların yarısı ise kararsız olduklarını belirtmişlerdir. İki ülke arasındaki uzaklık göz önünde bulundurulduğunda elde edilen dağılımın Türkçe eğitimi ve Türkiye’ye yönelik bir algının çıkarımı olarak olumlu olduğu söylenebilir.

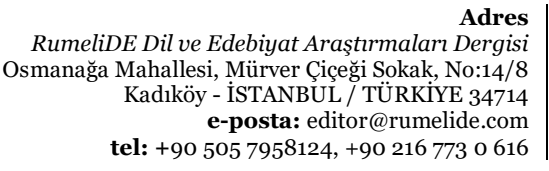

dres

isi

RumeliDE Journal of Language and Literature Studies

Osmanağa Mahallesi, Mürver Çiçeği Sokak, No:14/8

Kadıköy - ISTANBUL / TURKEY 34714

e-mail: editor@rumelide.com,

phone: +90 505 7958124, +90 2167730616 
3.23. Kolombiya'da Türkçe öğrenen bireylerin dil gereksinimlerinin tercümanlık yapma isteğine göre dağılımı:

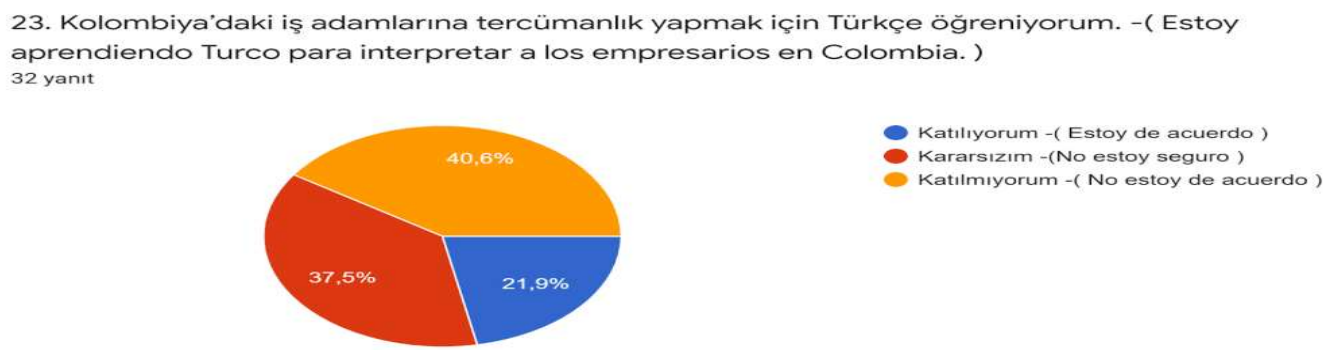

Şekil 23. Bireylerin dil gereksinimlerinin tercümanlık yapma amacına göre dağılımı

Şekil 23’te Kolombiya'da Türkçe öğrenen katılımcıların \%21’i Türkçe tercümanlık yapmak istediklerini belirtmişlerdir. Karasızlarla birlikte bu oran \%50'den fazladır. Bu dağılım ülkede Türkçe öğrenenler için tercümanlığın bir iş kolu olarak değerlendirebilecek olmasını göstermektedir.

\subsection{Kolombiya'da Türkçe öğrenen bireylerin dil gereksinimlerinin ülkedeki Türk şirketlerde çalışma amacına göre dağılımı:}

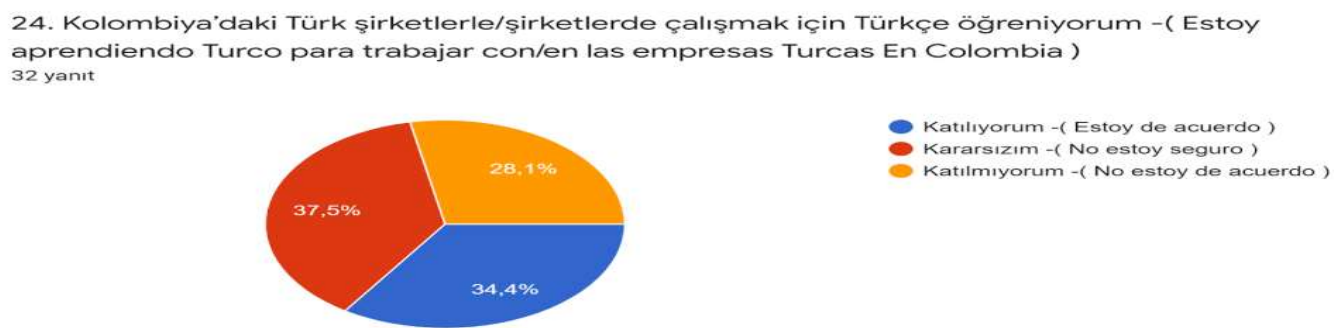

Şekil 24. Bireylerin dil gereksinimlerinin Türk şirketlerde çalışma amacına göre dağılımı

Şekil 24’te Kolombiya'da Türkçe öğrenen katılımcıların ülkedeki Türk şirketlerde çalışma amacına yönelik dağılımına bakıldığında katılımcıların \%34’ü "katılıyorum”, \%37’si ise "kararsızım” cevabını vermişlerdir. Bu oranlar öğrenenlerin dil gereksinimlerinde ekonomik faaliyetlerin bir gösterge olarak ele alınması gerektiğini göstermektedir.

RumeliDE Dil ve Edebiyat Araştırmaları Dergisi Osmanağa Mahallesi, Mürver Çiçeği Sokak, No:14/8 Kadıköy - ÍSTANBUL / TÜRKIYE 34714 e-posta: editor@rumelide.com tel: +90 505 7958124, +90 2167730616
Address

RumeliDE Journal of Language and Literature Studies

Osmanağa Mahallesi, Mürver Çiçeği Sokak, No:14/8

Kadıköy - ISTANBUL / TURKEY 34714

e-mail: editor@rumelide.com,

phone: +90 505 7958124, +90 2167730616 


\subsection{Kolombiya'da Türkçe öğrenen bireylerin dil gereksinimlerinin Türklerle konuşabilme amacına göre dağılımı:}

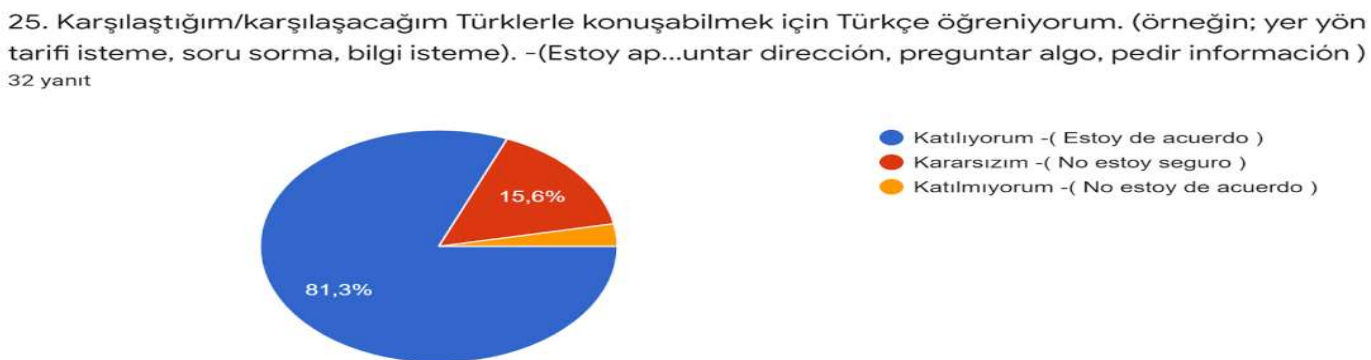

Şekil 25. Bireylerin dil gereksinimlerinin Türklerle konuşabilme amacına göre dağılımı

Şekil 25’te Kolombiya'da Türkçe öğrenen katılımcıların Türklerle konuşabilmek için Türkçe öğrenme durumlarına dair dağılımları gösterilmiştir. Katılımcıların \%81,3’ü buna "katıllyorum" cevabını vermişlerdir. Kararsızlarla birlikte bu oranın \%95’ten fazla olduğu anlaşılmaktadır. Elde edilen bu sonuçlar Kolombiyalıların Türklerle iletişim kurmak istediklerine yönelik güçlü bir algıyı göstermektedir.

\subsection{Kolombiya'da Türkçe öğrenen bireylerin dil gereksinimlerinin Türkçe öğretmenliği yapabilme amacına göre dağılımı:}

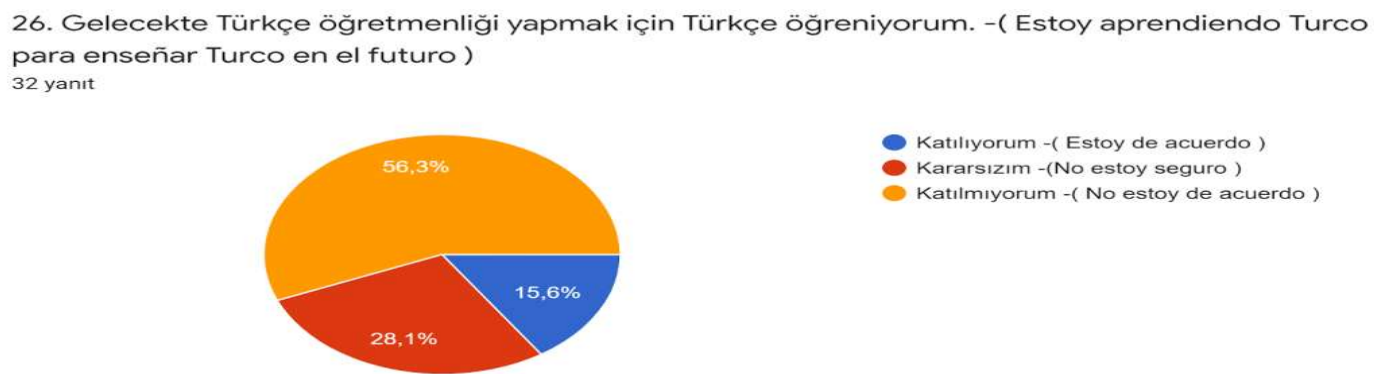

Şekil 26. Bireylerin dil gereksinimlerinin Türkçe öğretmenliği yapabilme amacına göre dağılımı

Şekil 26'da Kolombiya'da Türkçe öğrenen katılımcıların \%15,6'sı Türkçe öğretmenliği yapabilmek için Türkçe öğrendiğini belirtmiştir. Bu oldukça önemli bir dağılımdır. Çünkü bu oran ülkede Türkçe öğrenmeye yönelik bir isteğin olduğu şeklinde anlaşllabilir. Dolayısıyla Türkçe eğitimine yönelik faaliyetlerin artırılması gerekmektedir.

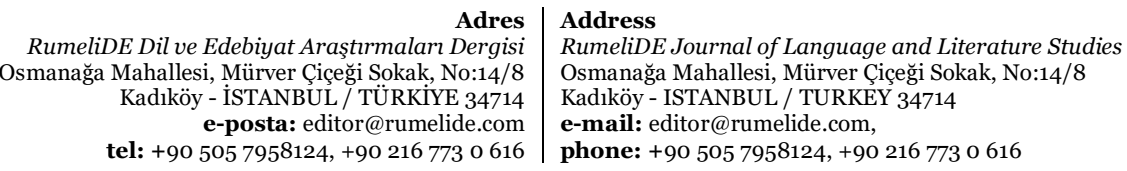




\subsection{Kolombiya'da Türkçe öğrenen bireylerin dil gereksinimlerinin ana dille Türkçe arasındaki yakınlığa yönelik öğrenme isteğine göre dağılımı:}

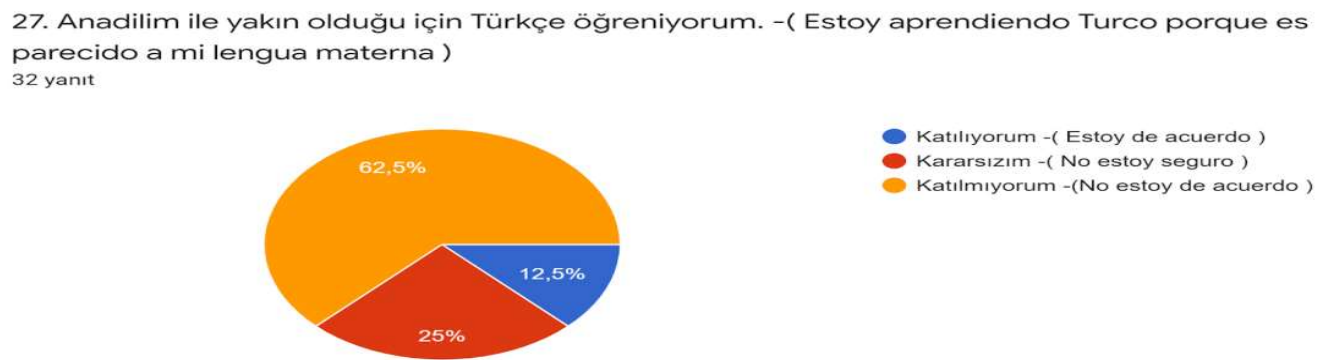

Şekil 27. Bireylerin dil gereksinimlerinin ana dille Türkçe arasındaki yakınlığa göre dağılımı

Şekil 27'de Kolombiya'da Türkçe öğrenen katılımcıların ana dilleriyle Türkçe arasındaki yakınlığa ilişkin dă̆̆lımı da tespit edilmiştir. Şekil 6'da görülebileceği üzere öğrencilerin tamamının ana dillerinin İspanyolca olduğu tespit edilmişti. Dolayısıyla İspanyolcayla Türkçe arasında bir yakınlık olduğuna yönelik katılımcıların sadece \%12,5'inin "katılıyorum" cevabı verdikleri tespit edilmiştir. Fakat öğrencilerin \%62,5’inin "katılmıyorum”, \%25’inin ise "kararsızım” cevabı verdikleri de saptanmıştır. Bu sonuçlardan anlaşılmaktadır ki katılımcılar Türkçe ve İspanyolca arasındaki yakınlığa ilişkin farklı bakış açllarına sahiptirler. Elde edilen görüşlerden onların hangi nedenlerden ötürü düşüncelerinin çeşitlilik arz ettiğiyle ilgili çalışmalar yapılabilir. Böylelikle yapılacak çalışmalarla ana dili İspanyolca olanlara daha nitelikli bir Türkçe öğretimi konusunda bir katkı sağlanabilecektir.

\subsection{Kolombiya'da Türkçe öğrenen bireylerin dil gereksinimlerinin Türk kültürü, edebiyatı ve tarihini tanıyabilme amacına göre dağılımı:}

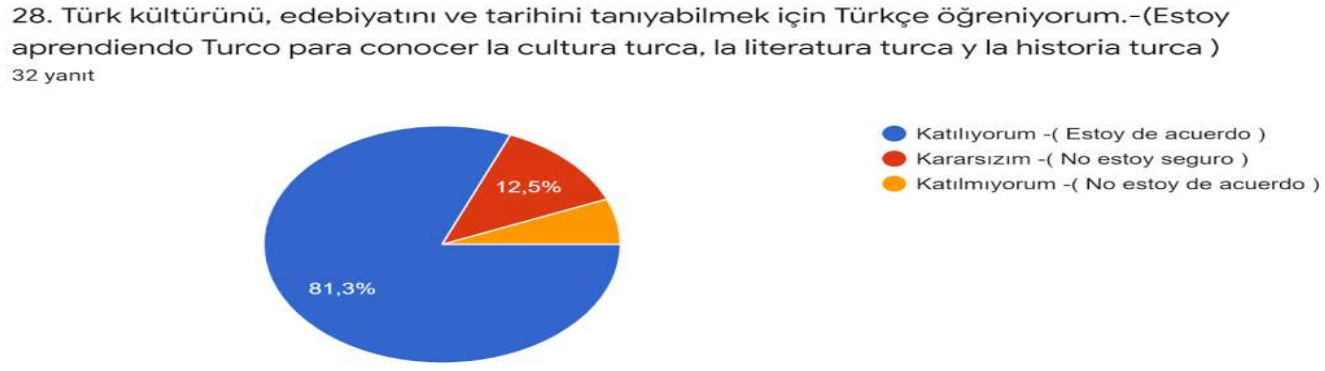

Şekil 28. Bireylerin dil gereksinimlerinin Türk kültürü, edebiyatı ve tarihini tanıyabilme amacına göre dağılımı

Şekil 28'de Kolombiya'da Türkçe öğrenenlerin Türk kültürü, edebiyatı ve tarihine yönelik algılarının tespitine yönelik dağılımına bakıldığında karasızlarla birlikte \%95'e yakın bir oranla karşılaşılmaktadır. $\mathrm{Bu}$ dağılım katılımcıların Türkiye’ye olan ilgilerinin ne denli güçlü olduğunun göstergesi olarak okunabilir.

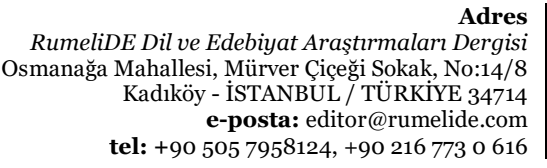

dres

isi

RumeliDE Journal of Language and Literature Studies

Osmanağa Mahallesi, Mürver Çiçeği Sokak, No:14/8

Kadıköy - ISTANBUL / TURKEY 34714

e-mail: editor@rumelide.com,

phone: +90 505 7958124, +90 2167730616 


\subsection{Kolombiya'da Türkçe öğrenen bireylerin dil gereksinimlerinin Türk şarkı, film ve dizileri anlayabilme amacına göre dağılımı:}

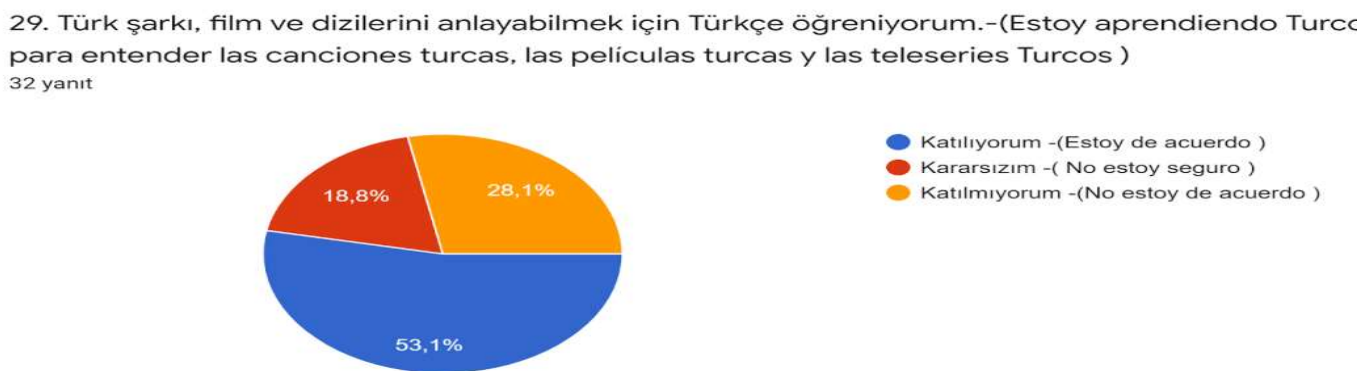

Şekil 29. Bireylerin dil gereksinimlerinin Türk şarkı, film ve dizileri anlayabilme amacına göre dağılımı

Şekil 29'da Kolombiya'da Türkçe öğrenenlerin Türk şarkı ve filmlerini anlayabilmeye yönelik dağılımlarına bakıldığında, \%53 oranında bu soruya "katılıyorum" cevabı verildiği anlaşılmaktadır. Ülkede son yllarda Türk dizilerine olan ilginin yüksek olduğu bilinen bir durumdur. Bunun öğrenenlerin dil tercihlerine de yansıdı̆̆ı görülmektedir. Nitekim Navarrete, (2020) "Kolombiya'da Türk dizilerinin etkisi” başlıklı yazısında başta Elif dizisi olmak üzere birçok Türk dizisinin ülkede en çok izlenen yayınlar arasında olduğunu belirtmektedir (s. 52-54). Türk dizilerine olan ilginin onları Türkçe öğrenmeye yönelttiği de bu çalışmayla daha net bir şekilde anlaşılmıştır.

\subsection{Kolombiya'da Türkçe öğrenen bireylerin dil gereksinimlerinin Türkiye'yi ve Türkleri kendilerine yakın hissetme durumuna göre dağılımı:}

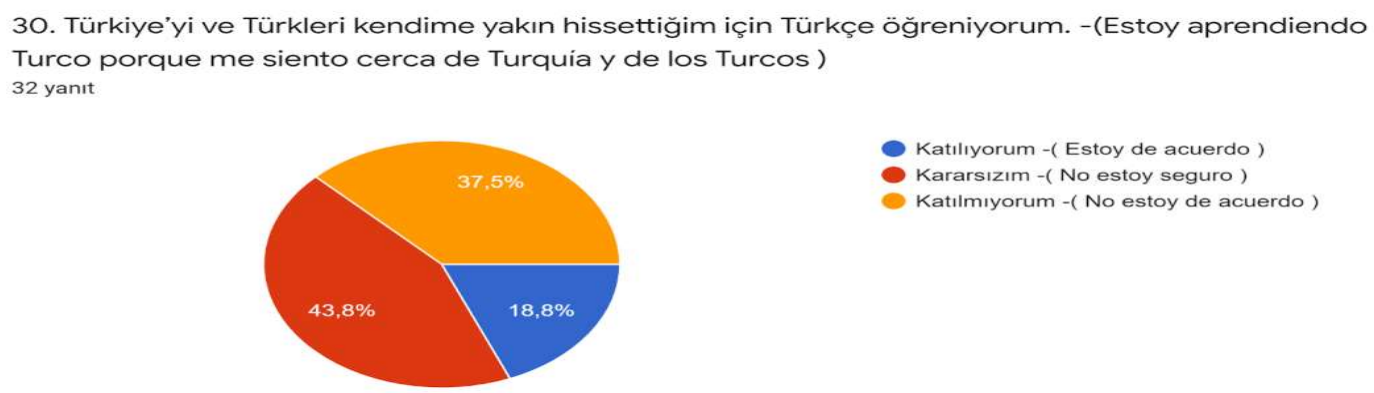

Şekil 30. Bireylerin dil gereksinimlerinin Türk şarkı, film ve dizileri anlayabilme amacına göre dağılımı

Şekil 30'da Kolombiya'da Türkçe öğrenen katılımcıların, kararsızlarla birlikte, \%6o'tan fazlasının Türkleri kendilerine yakın hissettikleri için Türkçe öğrendikleri anlaşılmaktadır. Geriye kalanların \%37'sinin ise bu duruma katılmadı̆̆ı tespit edilmiştir.

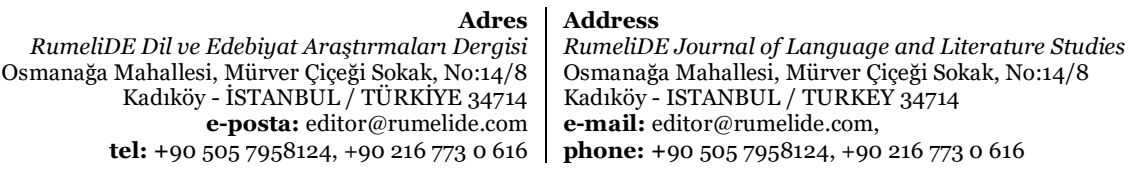




\subsection{Kolombiya'da Türkçe öğrenen bireylerin dil gereksinimlerinin Türkçeyi hobi olarak öğrenme isteğine göre dağılımı:}

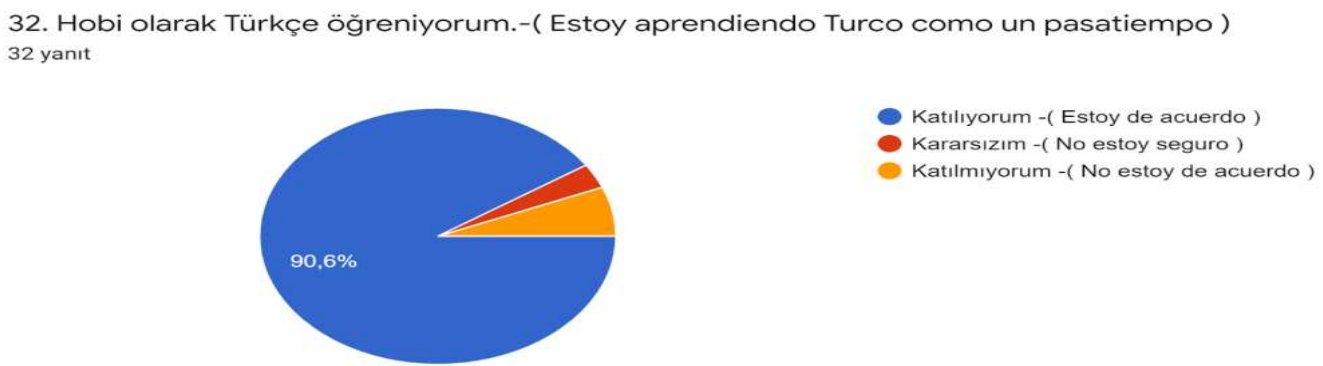

Şekil 31. Bireylerin dil gereksinimlerinin Türkçeyi hobi olarak öğrenme amacına göre dă̆ılımı

Şekil 31'de Kolombiya'da Türkçe öğrenen katılımcıların \%9o'dan fazlası hedef dili hobi olarak öğrendiklerini belirtmiştir. Bu durum Kolombiya’nın Türkiye’ye çok uzak bir bölgede yer almasına rağmen ülkede Türkçeye yönelik yüksek bir ilginin yansıması olarak görülmelidir.

\subsection{Kolombiya'da Türkçe öğrenen bireylerin dil gereksinimlerinin kişisel gelişimi artırma amacına göre dağılımı:}

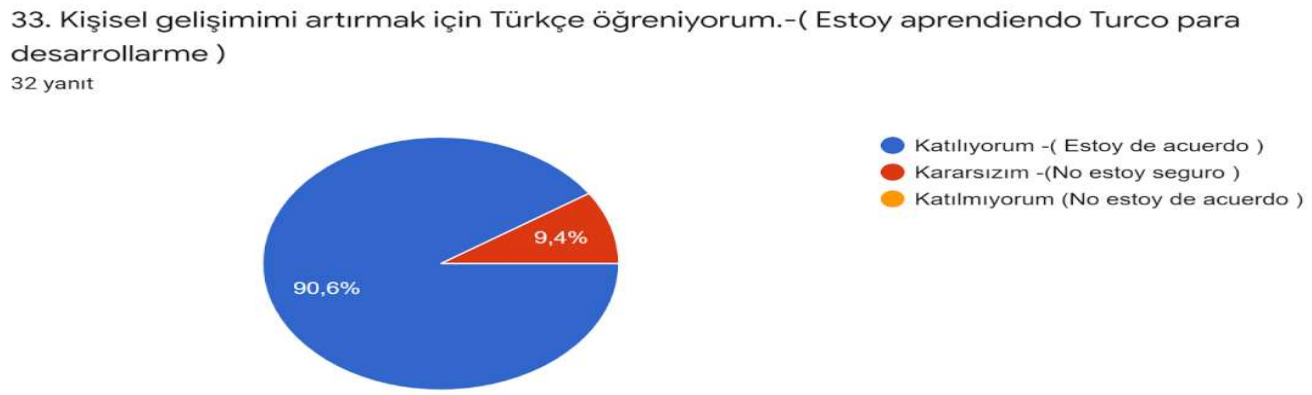

Şekil 32. Bireylerin dil gereksinimlerinin kişisel gelişimi artırma amacına göre dağılımı

Şekil 32'de Kolombiya'da Türkçe öğrenen katılımclların kişisel gelişimlerini artırmak için Türkçe öğrendikleri anlaşılmaktadır. Nitekim katılımcıların \%9o'dan fazlası bu duruma katıldıklarını belirtmiş̧tir. Kararsızlarla birlikte bu dağılım \%100’e ulaşmaktadır. İlgili soru kapsamında bu düşünceye "katılmıyorum" cevabının verilmemiş olması çok önemli bir göstergedir. Çünkü bu dağılım Türkçe öğrenenlerin tamamının hedef dilin onların kişisel gelişimine katkı sunduğunu ya da sunabileceğinin sonucu olarak açıklanabilir.

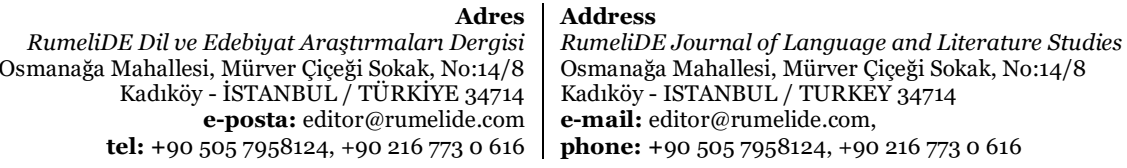




\subsection{Kolombiya'da Türkçe öğrenen bireylerin dil gereksinimlerinin Türkçenin dünyada en çok kullanılan dillerden biri olma durumuna göre dağılımı:}

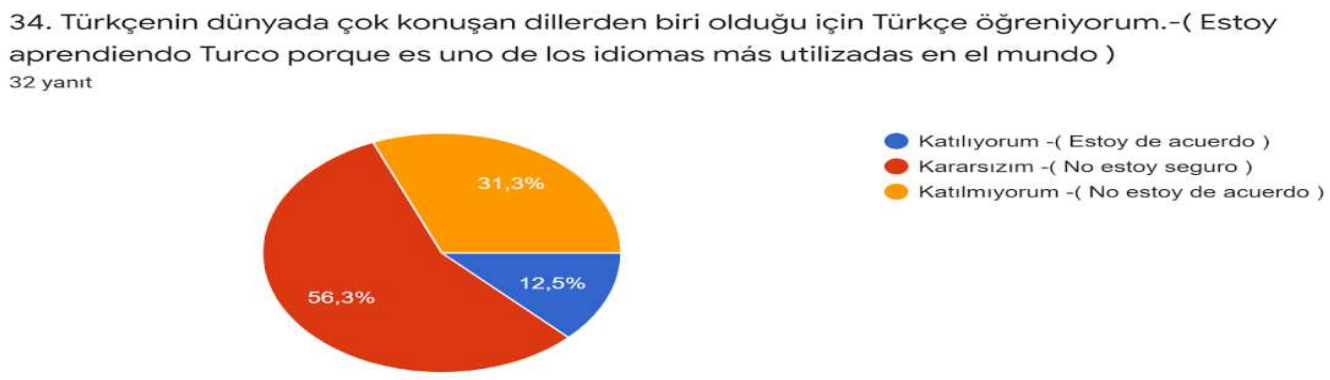

Şekil 33. Bireylerin dil gereksinimlerinin Türkçenin yaygın bir dil olma amacına göre dağılımı

Şekil 33’te katılımcıların Türkçenin dünyada en çok konuşulan dillerden biri olduğuna ilişkin dağılımı gösterilmiştir. Buna göre katılımcıların sadece \%12,5’i bu düşünceye katıldığını belirtmiştir. Kararsızların oranı ise \%56,3’tür. Türkçeye yönelik faaliyetlerin birkaç yıldır başladığı ve Türkiye'ye uzaklı̆̆ı bilinen bir ülkede bu denli bir dağılım önemli görülmeli ve bu çerçevede ülkede Türkçe öğretimine yönelik faaliyetlerin artırılması gerektiği açıktır. Böylece bu oranların çok daha fazla artacağı öngörülebilir.

\section{Sonuç ve öneriler}

$\mathrm{Bu}$ bölümde Kolombiya'da Türkçe öğrenen katılımclların Türkçe dil gereksinimlerinin tespiti sonucunda ortaya çıkan hususların açıklığa kazandırılması amaçlanmıştır. Fakat genel anlamda ise bulgulardan elde edilen sonuçlar çerçevesinde Kolombiya'da Türkçe öğretiminin değerlendirilmesi yoluna gidilerek birtakım öneriler geliştirilmiş ve bunlar maddeler halinde sıralanmıştır:

Kolombiya, Türkiye ilişkilerinin geleceğe daha güçlü taşınabilmesi amacıyla dil ve kültür alanında yapılan çalışmaların sistemli bir şekilde yürütülmesine yönelik çalışmalar üzerinde yoğunlaşılmalıdır. Bu çerçevede ülkede Türkçeye olan talep dikkate alınarak Türkçenin seçmeli ders olarak okutulduğu Ulusal Üniversitesi gibi büyük üniversitelerde Türkoloji bölümlerinin kurulması konusunda elçilik tarafından çalışmalar yapılmalıdır. Böylece ana dili İspanyolca olan Türkologların yetişmesi sağlanacak ve gerek öğrencilerin dil gelişimi açısından gerekse ülkede Türkçe öğretimine yönelik bir zemin oluşacaktır. Derslerin düzeye ve ihtiyaca göre belirlenebilmesi, Türkçe faaliyetlerinin her zaman takibi ya da yürütülmesi gibi birçok hususta da gerek şu an gerekse uzun vadede Kolombiyalı Türkologlara ihtiyaç olduğu/olacağı açıktır.

Türkiye ve Kolombiya arasında burs programlarına öğrenci kabulünde Türkçenin yabancı dil olarak öğretimi alanında uzmanlaşacak öğrencilere yer verilmesinin oldukça faydalı olacağı düşünülmektedir. Bu konuda farklı alanlarda Türkiye burslarıyla Türkiye’ye gelip öğrenim gören öğrencilerin olduğu tespit edilmiştir. Nitekim son yıllarda Kolombiya'ya yönelik Türkiye'de yapılan çalışmalardan da bu gelişmeler anlaşılabilir. Örneğin Ulusal Tez Merkezinden (2021) yapılan araştırmada arama terimi olarak "Kolombiya" yazıldığında çıkan araştırmaların neredeyse tamamının son on yılda yapılan tezlerden oluştuğu ve önemli bir kısmının da Kolombiyalı öğrenciler tarafından yazıldığı görülmektedir. 3 tezin doktora, geriye kalan 28'inin ise yüksek lisans tezi olduğu ve farklı alanlarda yazıldığı tespit edilen bu çalışmalar içerisinde dil eğitimine yönelik bir çalışmaya rastlanmamıştır. Dolayısıyla iki ülke ilişkilerine

Adres | Address

RumeliDE Dil ve Edebiyat Araşturmalar Dergisi $\quad$ RumeliDE Journal of Language and Literature Studies

Osmanağa Mahallesi, Mürver Çiçeği Sokak, No:14/8 Osmanağa Mahallesi, Mürver Çiçeği Sokak, No:14/8

Kadıköy - ÍSTANBUL / TÜRKIYE 34714 Kadıköy - ISTANBUL / TURKEY 34714

e-posta: editor@rumelide.com e-mail: editor@rumelide.com,

tel: +90 505 7958124, +90 2167730616 phone: +90 505 7958124, +90 2167730616 
katkı sunacak dile yönelik çalışmaların artması ve ülkede Türkçe öğretimini yapabilecek Kolombiyalı öğreticilerin de yetişmesinin gerekliliği açıktır.

Yapılan çalışmada Kolombiya'da Türkçe öğrenenlerin dil gereksinimlerinin tespit edilmesine yönelik 33 sorudan oluşan bir anket uygulanmıştır. Buna göre katılımcıların yaş, cinsiyet, ana dil başta olmak üzere birçok değişkenlere yönelik dağılımı belirlenmiştir. Elde edilen oranlar çerçevesinde ülkede Türkçe öğrenenlerin dil gereksinimlerine yönelik sonuçlara bakıldığında katılımcıların cinsiyet oranlarının birbirine yakın olduğu, yaşlarının 28 yaş ve altında bireylerden oluştuğu tespit edilmiştir. Ana dillerinin tamamının İspanyolca olduğu katılımcıların \%93,8'inin lisans, geriye kalan katılımcıların ise lise ve yüksek lisans öğrencileri oldukları görülmüştür. Nitekim mesleki durumlarına yönelik dağılıma da bakıldığında katılımcıların yüzde 93,8'inin öğrenci olduğu saptanmıştır. Bu çerçevede ülkede Türkçe öğrenenlerin gençler olduğu belirlenmiştir. Türkçe kurs merkezlerinin açılmasıyla her yaş grubundan öğrencinin artacağı öngörülse de daha çok gençler arasında bir tercih olarak Türkçe öğrenmeye olan istek ya da amacın oluşması olumlu bir gelişmedir.

Katılımcıların tamamının ana dillerinin, ülkenin de resmi dili olan, İspanyolca olduğu belirlenmiştir. Fakat öğrenenlerin ikinci dil olarak \%93,8 oranında İngilizce, \%6,2'sinin de Fransizca olduğu saptanmıştır. Ülkede farklı etnik toplulukların olduğu bilinmektedir. Özellikle azımsanmayacak bir oranda Orta Doğu ve Afrika'dan ülkeye göç etmiş olanların olduğu bilinen bir durumdur. Bu çerçevede ülkede Türkiye'yle ortak tarihi, dini, kültürel değerlere sahip olan bireylerin çeşitli nedenlerle Türkçe öğrenme istekleri mümkün olabilir. Bunun için de Türkçe öğretimine yönelik faaliyetlerin artırılması gerekebilir.

Kolombiya'da Türkçe öğretimi belirli üniversitelerde seçmeli ders olarak okutulduğu için katılımcıların da Türkçe öğrenme süreleri seçmeli derslerle sınırlı kalmaktadır. Bu nedenle katılımcıların nerdeyse tamamına yakınının 0-4 ay arasında Türkçe öğrendikleri tespit edilmiştir. Geriye kalan yüzde 5'lik kesimin de seçmeli olarak Türkçe A2 adlı derse kayıt yapan öğrenciler olabileceği düşünülmektedir. Bu tespitler çerçevesinde denilebilir ki ülkede Türkçe öğretimine yönelik Türkoloji bölümlerinin açılması ya da Yunus Emre Enstitüsü gibi merkezlerin burada da faaliyet göstermesi gerekmektedir.

Katılımcıların nerdeyse tamamına yakınının Türkiye’ye gelmedikleri tespit edilmiştir. Dolayısıyla Türkçe ediniminin de daha çok sınıfla sınırlı kaldığı söylenebilir. Nitekim katılımcıların \%44'e yakını Türkçeyi sınıf dışında hiç kullanmadıklarını \%28,1’i ise nadiren kullandıklarını belirtmiştir. Diğer katılımcıların büyük bir çoğunluğunun ise sosyal medyada Türkçe bilenlerle mesajlaşırken Türkçeyi kullandıkları saptanmıştır. Dolayısıyla ilgili ülkede Türkçe konuşanların sınırlı oluşu katılımcılar için dili kullanma noktasında bir sinırlılık oluşturmaktadır.

Kolombiya'da Türkçe öğrenenlerin yarısından fazlası, \%53,1'i, turist olarak; \%43,8’i ise öğrenci değişim programı için Türkiye'ye gelmek istediklerini belirtmişlerdir. Bunun dışında \%5'e yakın bir oranda da iş amacıyla gelinmek istendiği görülmektedir. Özellikle öğrenci değişim programları konusunda öğrencilerin yarısına yakınının Türkçe öğrenme isteğinin olması Türkiye’ye yönelik güçlü bir algının göstergesi olarak okunabilir. Nitekim katılımcıların \%43’ü’nün Türkiye'de bulunan bir yükseköğretim kurumunda eğitim almak istedikleri de bir başka madde kapsamında saptanmıştır.

Katılımcıların Türkçe öğrenme gereksinimlerinin uzmanlık alanlarıyla ilişkili dağılımına bakıldığında kararsızlarla birlikte katılımcıların \%9o'dan fazlasının bu düşünceye katıldığı tespit edilmiştir. Dolayısıyla ülkede Türkçe öğrenenlerin hedef dil konusunda daha da yetkin olma isteği taşıdıkları

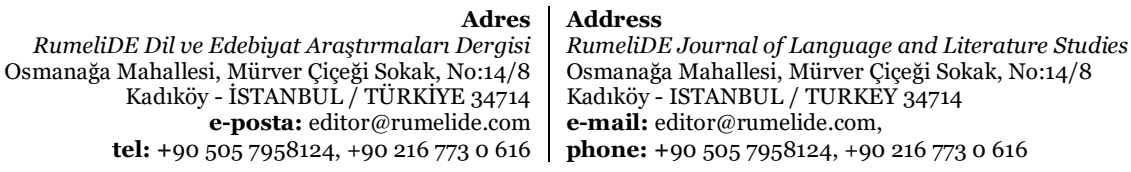


söylenebilir. Türkçeyi farklı bölümlerden öğrencilerin seçmeli ders olarak tercih edişi elde edilen sonuçlarla ilişkilendirilebilir. Bu çerçevede ülkede sürekli Türkçe öğretimine yönelik bölüm ya da merkezlerin olması önemli görülmelidir.

Kolombiya'da Türkçe öğrenen katılımcıların \%43,8’i burs, iş vb. resmi işlere katılabilmek amacıyla Türkçe öğrenmek istediklerini belirtmişlerdir. Kararsızlarla birlikte katılımcıların \%9o’a yakınının konuya yaklaşımı bu ülkede Türkçe öğrenme faaliyetlerinin amacını ortaya koyması bakımından önemli görülebilir. Her ülkede ekonomik faktörlerin dil öğrenmede etkili olduğu bilinen bir durumdur. Bu çerçevede katılımcıların buna yönelik dağılımı normal bir durumdur. Fakat öğrenenlerin Türkçeye yönelik böyle bir algılarının oluşu üzerinde etkili olan hususların neler olduğu üzerinde farklı çalışmalar yapilabilir.

Kolombiya'da Türkçe öğrenenlerin yüksek oranda Türkiye'ye tatile gitme amacı taşıdıkları tespit edilmiştir. Bu çerçevede turizm alanında Türkiye'nin tanıtımına yönelik çalışmaların yürütülmesi her anlamda faydalı olacaktır. Nitekim çalışmada katılımcıların Türkiye'de yaşama isteğine yönelik dağılımına da bakılmıştır. Buna göre \%31 oranında "katılıyorum" cevabının verilmesi bireylerde Türkiye algısının güçlü olduğunu göstermektedir. $\mathrm{Bu}$ oran karasızlarla birlikte \%70’e yakın bir orana çıkmaktadır.

Katılımcıların \%71,9’u Türkçe öğrenmenin onlara yeni iş imkânları oluşturacağı düşüncesini taşımaktadır. Kararsızlarla birlikte bu oran \%9o'dan fazla bir orana yükselmektedir. Dolayısıyla Türkçe öğrenme noktasında öğrencilerin yeni imkânlara kavuşabilme ümidine yönelik bir düşünce taşımaları burada Türkçe faaliyetlerinin geliştirilmesi başta olmak üzere iki ülke arasındaki ilişkilerin daha da ileriye taşınması noktasında da bir fikir verdiği söylenebilir. Nitekim öğrenenlerin Türkiye'de bir meslek alanında çalışabilme, tercümanlık yapma, ülkedeki Türk şirketlerde çalışabilme, Türkçe öğretmenliği yapabilme amacına yönelik de Türkçe öğrendikleri tespit edilmiştir.

Kolombiya'da Türkçe öğrenen katılımcıların ana dillerinin tamamının İspanyolca olduğu tespit edilmiştir. Katılımcıların sadece \%12,5’i İspanyolcayla Türkçe arasında bir yakınlık olduğunu belirtmiştir. Buna karşın \%62,5’i "katılmıyorum", \%25”i ise "kararsızım" cevabını vermiştir. Elde edilen oranlardan anlaşılmaktadır ki katılımcılar Türkçe ve İspanyolca arasındaki yakınlığa ilişkin farklı bakış açlarına sahiptir. Bu çerçevede elde edilen bu görüşlerin hangi nedenlerden ötürü çeşitlilik arz ettiğiyle ilgili çalışmalar yapılabilir. Böylelikle yapılacak çalışmalarla ana dili İspanyolca olanlara daha nitelikli bir Türkçe öğretimi konusunda bir katkı sağlanabilecektir.

Çalışmada katılımcıların Türk kültürü, edebiyatı ve tarihine yönelik olumlu bir algıya sahip oldukları ve Türkleri kendilerine yakın gördükleri sonucuna ulaşılmıştır. Bu olumlu görüşlerin yapılacak çalışmalarla daha da güçlenmesinin ülkeler arası ilişkiye katkı sağlayacağı açıktır.

Katılımcıların \%9o'dan fazlasının Türkçeyi hobi olarak öğrendikleri de tespit edilmiştir. Benzer şekilde kişisel gelişimlerini artırmak için de Türkçe öğrenenlerin oranı \%9o'dan fazladır. Hatta kararsızlarla birlikte bu dağılımın \%10o’e ulaştığı görülmektedir. Dolayısıyla ülkede Türkçe öğrenmek için gelenlerin hedef dile ilişkin bu kanaatleri ülkede yapılacak etkinlik ya da çalışmalar hakkında bir fikir verebilmesi konusunda değerli görülmelidir. Nitekim katılımcıların Türkçenin dünyada en çok konuşulan dillerden biri olduğuna ilişkin olumlu görüşler ortaya koyması da bu çerçevede değerlendirilebilir.

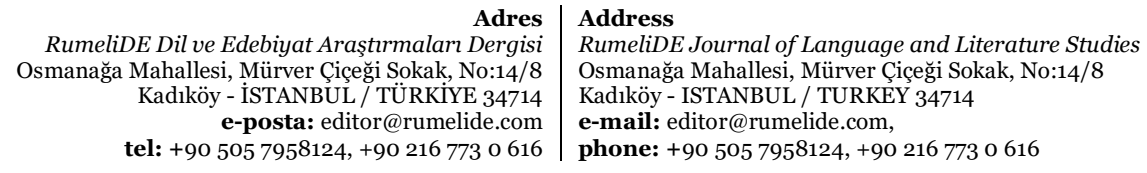


Kolombiya'da son yıllarda Türk dizilerinin çok rağbet gördüğü bilinmektedir. Nitekim Navarrete, (2020) "Kolombiya'da Türk Dizilerinin Etkisi” başlıklı yazısında başta Elif dizisi olmak üzere birçok Türk dizisinin ülkede en çok izlenen yayınlar arasında olduğunu belirtmektedir (s. 52-54). Bu çerçevede çalışmada katılımcıların dil gereksinimlerinin Türk şarkı ve filmleri anlayabilmeye yönelik dağılımına da bakılmış ve bunun sonucunda \%53 gibi bir oranla karşılaşılmıştır. Kararsızlarla birlikte bu oranın \%70’in üstüne çıtığı tespit edilmiştir. Türk dizilerine olan ilginin onları Türkçe öğrenmeye yönelttiği de bu çalışmayla daha net bir şekilde anlaşılmıştır.

Kolombiya'da Türkçe öğretimine yönelik faaliyetlerin gerek tarihsel, dinsel, kültürel vb. mirasın ortak olduğu bireylerle kurulan ilişkilerin geliştirilmesine gerekse ülke aleyhine yürütülen ya da yürütülecek güncel/tarihi iddia veya çarpıtmaların önüne geçme adına önemli olduğu düşünülmektedir. Bu nedenle özelde Kolombiya genelde ise Latin Amerika ülkelerinde Türkçe öğretimine yönelik faaliyetler önemsenmeli ve bunun geliştirilmesi konusunda çaba sarf edilmelidir. Özellikle Yunus Emre Enstitüsünün Latin Amerika ülkelerinde faaliyetlerini artırmasına yönelik çalışmalar içerisine girmesinin oldukça yararlı olacağı düşünülmektedir.

\section{Kaynakça}

Aypay, A., Cemaloğlu, N., Sarpkaya, R., Ellez, A. M., Şahin, B., Tomul, E. ve Turgut, Y. (2009). Bilimsel araştırma yöntemleri. Ankara: Anı Yayıncılık.

Büyüköztürk, Ş., Kılıç-Çakmak, E., Akgün, Ö. E., Karadeniz, Ş. ve Demirel, M. (2014). Bilimsel araştırma yöntemleri. Ankara: Pegem Akademi.

Castellanos, D. G. (2010). Islam en Bogotá: presencia inicial y diversidad. Bogotá: Universidad del Rosario.

Çangal, Ö. (2013). Yabancllara Türkçe öğretiminde dil ihtiyaç analizi: Bosna Hersek örneği. [Yayınlanmamış yüksek lisans tezi]. Gazi Üniversitesi.

Karasar, N. (1999). Bilimsel araştırma yöntemi. Ankara: Nobel Yayınevi.

Navarrete, N. A. (2020). Ülke imajının oluşmasında televizyon yayınlarının rolü: Türk dizilerinin Kolombiyalılarda oluşturduğu Türkiye imajı. [Yayınlanmamış yüksek lisans tezi]. Marmara Üniversitesi.

TíkA - Türk İşbirliği ve Koordinasyon Başkanlı̆̆ (2021). https://www.tika.gov.tr/tr/ara?s=tika+kolombiya. [Erişim Tarihi. 29.10.2021].

Wikipedia (2021). https://tr.wikipedia.org/wiki/Kolombiya-T\%C3\%BCrkiye_ili\%C5\%9Fkileri. [Erişim Tarihi. 29.10.2021].

Ulusal Tez Merkezi (2021). https://tez.yok.gov.tr/UlusalTezMerkezi/tezSorguSonucYeni.jsp. [Erişim Tarihi. 30.10.2021].

Zuluaga González, P. L. (2019). Geçmişten günümüze Kolombiya’da İslam. [Yayınlanmamış yüksek lisans tezi]. Sakarya Üniversitesi.

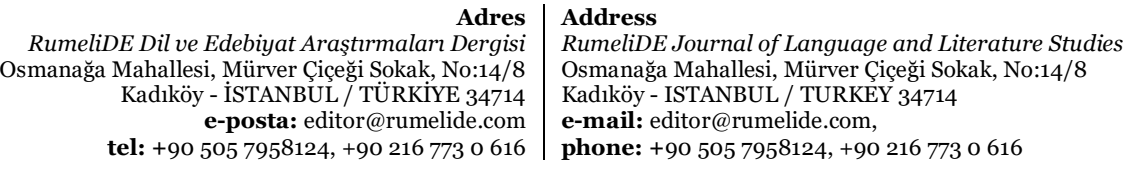

